
Periodica Polytechnica
Civil Engineering

61(2), pp. 256-271, 2017

https://doi.org/10.3311/PPci.9359

Creative Commons Attribution (i)

RESEARCH ARTICLE

\section{Effect of Calcium Sulphate on the Geotechnical Properties of Stabilized Clayey Soils}

\author{
Hamid Gadouri $^{1 *}$, Khelifa Harichane ${ }^{2}$, Mohamed Ghrici ${ }^{2}$
}

Received 20 April 2016; Accepted 25 May 2016

\begin{abstract}
An experimental investigation was undertaken to study the effect of calcium sulphate $\left(\mathrm{CaSO}_{4} \cdot 2 \mathrm{H}_{2} \mathrm{O}\right)$ on the behaviour of the grey clay (GS) and red clay (RS) soils stabilized with lime (L), natural pozzolana (NP) and their combination (L-NP). In this study, the geotechnical properties investigated are respectively, the Atterberg limits on samples cured for 1 to 30 days to assess the diffusion time effect of $\mathrm{CaSO}_{4} \cdot 2 \mathrm{H}_{2} \mathrm{O}$ (DTC) in the soil paste and the unconfined compressive strength (UCS) on samples cured for 7 to 120 days. The results show that both GS and RS samples can be successfully stabilized with L alone or with L-NP which substantially reduce their plasticity index (PI) and increase their UCS. On the other hand, a negligible effect was reported when the NP is used alone. However, when combining a fraction of $\mathrm{CaSO}_{4} \cdot 2 \mathrm{H}_{2} \mathrm{O}$ to samples containing $\mathrm{L}$ or L-NP, a further decrease in the PI is observed. In addition, higher UCS values are recorded.
\end{abstract}

\section{Keywords}

Clayey soil, lime (L), natural pozzolana (NP), calcium sulphate, plasticity index (PI), unconfined compressive strength (UCS)

\footnotetext{
${ }^{1}$ Department of Matter Engineering

Faculty of Sciences and Technology,

Medea University, Medea 26000, Algeria

${ }^{2}$ Department of Civil Engineering,

Faculty of Civil Engineering and Architecture,

Chlef University, Chlef 02000, Algeria

BP 151 Hay Salem 02000, Algeria

${ }^{*}$ Corresponding author, e-mail: hamid_gadouri2000@yahoo.fr
}

\section{Introduction}

Civil engineering projects located in areas with inappropriate soils is one of the most frequent problems in the world. Soil stabilization technique has been practiced for several years with the main aim to render the soils capable of meeting the requirements of the specific engineering projects [1]. Hydraulic binders (cement and L) were used as stabilizers in various civil engineering fields. Soils stabilization is a technique that requires the use of hydraulic binders alone or in combination with other mineral additives such as fly ash. Extensive studies have been carried out to study the different effects produced by the use of cement alone or in combination with L [2-4], rice husk ash, [5-7] and fly ash [8,9] on physico-mechanical properties of soils.

In the absence of sulphates, the reduction in the repulsion forces between the clay particles (due to the L addition) creates a bond between them and forms flocks. This change caused by $L$ reduces the plasticity index and the maximum dry density of the stabilized soil but increases their optimum moisture content [10]. At the later stage, the increase in the concentration of hydroxyl $\left(\mathrm{OH}^{-}\right)$from $\mathrm{L}$ raises the $\mathrm{pH}$ of the soil, and causes the dissolution of alumina and silica which interact with calcium ions to form cementing products such as calcium silicate hydrates $(\mathrm{CSH})$ and calcium aluminate hydrates $(\mathrm{CAH})$. The formation of these compounds is responsible on the increase in unconfined compressive strength (UCS) values of the stabilized soil [11] and their shear strength values [12].

However, in the presence of sulphates, the sulphate ions react with calcium, hydroxyl and aluminium compounds to form expansive phases such as ettringite. Furthermore, the magnitude of damage caused by the ettringite depends on the soil nature, the type and the content of additives [3] and the concentration and the type of cation associated with the sulphate anion [13]. Indeed, the effects caused by the presence of different types of sulphates on the geotechnical properties of soils stabilized with additives have been investigated by several researchers [13-19]. 
The combination of volcanic materials with $\mathrm{L}$ produces a beneficial effect on the behaviour of the stabilized soil [9]. The NP is found in abundance in areas of Beni-Saf located in the west of Algeria [20]. The NP was used in combination with L to improve the engineering properties of both GS and RS such as the shear strength, the plasticity and the UCS $[10,11,21,22]$. However, there is no investigation of the influence of $\mathrm{CaSO}_{4} \cdot 2 \mathrm{H}_{2} \mathrm{O}$ on the stabilization of these soils. This work is devoted mainly for study the effect of $\mathrm{CaSO}_{4} \cdot 2 \mathrm{H}_{2} \mathrm{O}$ on the Atterberg limits and UCS of the same soils (GS and RS) using L, NP and their combination.

\section{Materials Used and Identification}

\subsection{Soils}

In the present study, two soils were used, the first is a grey clay soil (GS) which was obtained from an embankment project site, and the second is a red clay soil (RS) which was obtained from a highway project site, and both near Chelif town in the West of Algeria. The soil was excavated, placed in plastic bags and transported to the laboratory for preparation and testing. Laboratory tests were carried out to classify each type of soil (Fig. 1a).

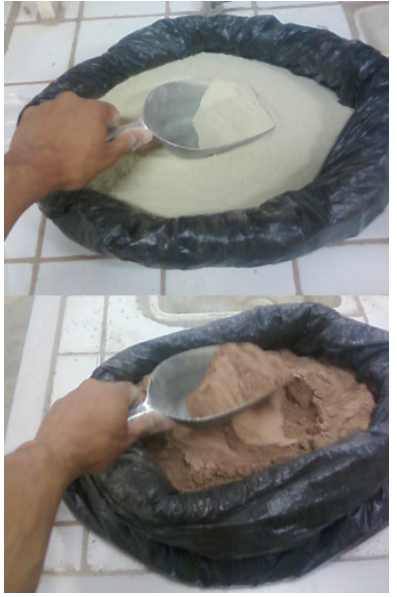

(a)

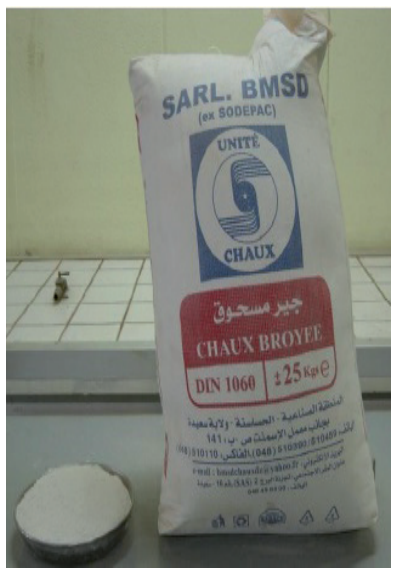

(c)

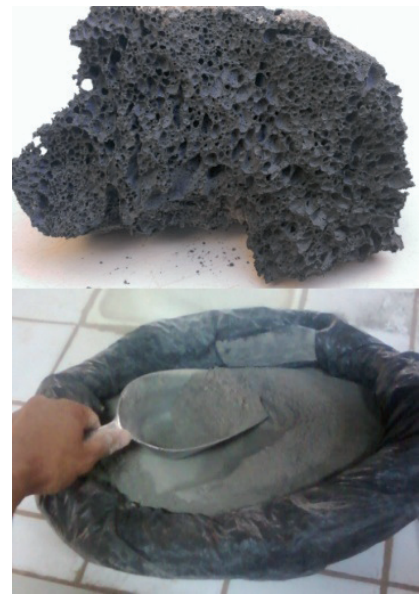

(b)

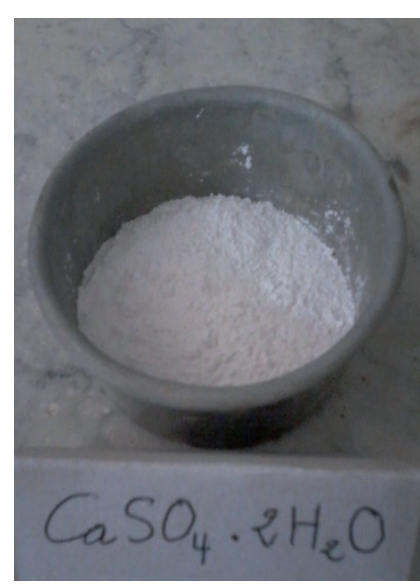

(d)
Fig. 1 Materials used and their preparation; (a) clayey soils passed to $1 \mathrm{~mm}$ sieve, (b) NP before and after preparation, (c) hydrated lime usually used for construction purposes and (d) calcium sulphate
The Physico-mechanical properties of both clayey soils are presented in Table 1. The chemico-mineralogical properties of both clayey soils are depicted in Table 2.

\subsection{Mineral additives}

The NP used in this study was collected from Beni-Saf located in the Western of Algeria. It was ground to the specific surface area of $420 \mathrm{~m}^{2} / \mathrm{kg}$ (Fig. 1b). The L used in this study is commercially available L typically used for construction purposes (Fig. 1c). The physico-chemical properties of L and NP are presented in Table 3 .

Table 1 Physico-mechanical properties of both clayey soils (After [11])

\begin{tabular}{lcc}
\hline Physico-mechanical properties & GS & RS \\
\hline Depth (m) & 4.00 & 5.00 \\
Natural water content (\%) & 32.90 & 13.80 \\
Specific Gravity & 2.71 & 2.84 \\
Passing $80 \mu$ m sieve (\%) & 85.00 & 97.50 \\
Liquid Limit (LL, \%) & 82.80 & 46.50 \\
Plastic Limit (PL, \%) & 32.20 & 22.70 \\
Plasticity Index (PI, \%) & 50.60 & 23.80 \\
Classification System (USCS) & $\mathrm{CH}$ & $\mathrm{CL}$ \\
Optimum Moisture Content $\left(\mathrm{W}_{\mathrm{OPN}}, \%\right)$ & 28.30 & 15.30 \\
Maximum Dry Density $\left(\gamma \mathrm{d}_{\max }, \mathrm{kN} / \mathrm{m}^{3}\right)$ & 13.80 & 16.90 \\
Unconfined Compressive Strength $(\mathrm{UCS}, \mathrm{KPa})$ & 100 & 510 \\
Loss on ignition $(\%)$ & 17.03 & 7.13 \\
\hline
\end{tabular}

Table 2 Chemico-mineralogical properties of both clayey soils

\begin{tabular}{|c|c|c|c|}
\hline $\begin{array}{l}\text { Chemical or min- } \\
\text { eralogical name }\end{array}$ & Chemical formula & $\begin{array}{l}\text { GS } \\
(\%)\end{array}$ & RS (\%) \\
\hline Calcium oxide & $\mathrm{CaO}$ & 14.43 & 2.23 \\
\hline Magnesium oxide & $\mathrm{MgO}$ & 1.99 & 2.14 \\
\hline Iron oxide & $\mathrm{Fe}_{2} \mathrm{O}_{3}$ & 5.56 & 7.22 \\
\hline Alumina & $\mathrm{Al}_{2} \mathrm{O}_{3}$ & 14.15 & 19.01 \\
\hline Silica & $\mathrm{SiO}_{2}$ & 43.67 & 57.02 \\
\hline Sulfite & $\mathrm{SO}_{3}$ & 0.04 & 0.19 \\
\hline Sodium oxide & $\mathrm{Na}_{2} \mathrm{O}$ & 0.34 & 0.93 \\
\hline Potassium oxide & $\mathrm{K}_{2} \mathrm{O}$ & 1.96 & 3.17 \\
\hline Titan dioxide & $\mathrm{TiO}_{2}$ & 0.65 & 0.83 \\
\hline Phosphorus & $\mathrm{P}_{2} \mathrm{O}_{5}$ & 0.18 & 0.14 \\
\hline $\mathrm{pH}$ & - & 9.18 & 9.05 \\
\hline Calcite & $\mathrm{CaCO}_{3}$ & 26.00 & 4.00 \\
\hline Albite & $\mathrm{NaAlSi}_{3} \mathrm{O}_{8}$ & - & 8.00 \\
\hline Illite & $2 \mathrm{~K}_{2} \mathrm{O} \cdot \mathrm{Al}_{2} \mathrm{O}_{3} \cdot 24 \mathrm{SiO}_{2} \cdot 2 \mathrm{H}_{2} \mathrm{O}$ & 16.00 & 24.00 \\
\hline Kaolinite & $\mathrm{Al}_{2} \mathrm{Si}_{2} \mathrm{O}_{5}(\mathrm{OH})_{4}$ & 12.00 & 16.00 \\
\hline Montmorillonite & $\mathrm{Al}_{2}\left(\left(\mathrm{Si}_{4} \mathrm{Al}\right) \mathrm{O}_{10}\right)(\mathrm{OH})_{2} \cdot \mathrm{H}_{2} \mathrm{O}$ & 20.00 & - \\
\hline Chlorite & $\mathrm{Mg}_{2} \mathrm{Al}_{4} \mathrm{O}_{18} \mathrm{Si}_{3}$ & - & 9.00 \\
\hline $\begin{array}{l}\text { Ferruginous } \\
\text { minerals }\end{array}$ & - & 6.00 & 7.00 \\
\hline Organic matter & - & 0.33 & - \\
\hline
\end{tabular}




\subsection{Chemical compound}

The chemical element used in this study is the calcium sulphate dihydrate $\left(\mathrm{CaSO}_{4} \cdot 2 \mathrm{H}_{2} \mathrm{O}\right)$ produced by Biochem Chemopharma which is a leading international Manufacturer and Supplier of Laboratory Reagents (Fig. 1d). The physico-chemical properties of this element are shown in Table 4.

Table 3 Physico-chemical properties of lime and natural pozzolana (After [11])

\begin{tabular}{|c|c|c|}
\hline $\begin{array}{l}\text { Physical or chemical } \\
\text { name }\end{array}$ & $\mathrm{L}(\%)$ & NP $(\%)$ \\
\hline Physical form & Dry white powder & Dry brown powder \\
\hline Specific Gravity & 2.00 & - \\
\hline Over $90 \mu \mathrm{m}(\%)$ & $<10.00$ & - \\
\hline Over $630 \mu \mathrm{m}(\%)$ & 0 & - \\
\hline Insoluble material (\%) & $<1.00$ & - \\
\hline Bulk density (g/L) & $600-900$ & - \\
\hline Loss on ignition & - & 5.34 \\
\hline $\mathrm{CaO}$ & $>83.30$ & 9.90 \\
\hline $\mathrm{MgO}$ & $<0.50$ & 2.42 \\
\hline $\mathrm{Fe}_{2} \mathrm{O}_{3}$ & $<2.00$ & 9.69 \\
\hline $\mathrm{Al}_{2} \mathrm{O}_{3}$ & $<1.50$ & 17.50 \\
\hline $\mathrm{SiO}_{2}$ & $<2.50$ & 46.40 \\
\hline $\mathrm{SO}_{3}$ & $<0.50$ & 0.83 \\
\hline $\mathrm{Na}_{2} \mathrm{O}$ & $0.40-0.50$ & 3.30 \\
\hline $\mathrm{K}_{2} \mathrm{O}$ & - & 1.51 \\
\hline $\mathrm{CO}_{2}$ & $<5.00$ & - \\
\hline $\mathrm{TiO}_{2}$ & - & 2.10 \\
\hline $\mathrm{P}_{2} \mathrm{O}_{3}$ & - & 0.80 \\
\hline $\mathrm{CaCO}_{3}$ & $<10.00$ & - \\
\hline
\end{tabular}

Table 4 Physico-chemical properties of calcium sulphate

\begin{tabular}{cc}
\hline Physico-chemical properties & Calcium sulphate \\
\hline Color & White \\
Chemical formula & $\mathrm{CaSO}_{4} .2 \mathrm{H}_{2} \mathrm{O}$ \\
Molar weight $(\mathrm{g} / \mathrm{mol})$ & 172.17 \\
Auuay (dried), (\%) & 99.0 \\
Insoluble matter $(\%)$ & 0.025 \\
Chloride (Cl, \%) & 0.002 \\
Nitrate (NO3, \%) & 0.002 \\
Ammonium (NH4, \%) & 0.005 \\
Carbonate (CO3, \%) & 0.05 \\
Heavy metals $(\mathrm{Pb}, \%)$ & 0.001 \\
\hline
\end{tabular}

\section{Test Procedures}

Laboratory tests on plasticity and UCS were conducted on both selected clayey soils. Several combinations of NP and $\mathrm{L}$ were used for their stabilization. These combinations were mixed with or without $\mathrm{CaSO}_{4} \cdot 2 \mathrm{H}_{2} \mathrm{O}$. A total of 72 combinations based on GS and RS is shown in Table 5 .

\subsection{Atterberg Limits Test}

Atterberg limits were performed according to ASTM D4318 [23]. The variations in the liquid limit (LL), plastic limit (PL) and plasticity index (PI) of two untreated clayey soils before and after admixtures added were studied.

Table 5 Combinations of both clayey soils studied

\begin{tabular}{|c|c|c|c|c|}
\hline \multirow{2}{*}{ Designation } & \multicolumn{4}{|c|}{ Sample mixture $(\%)$} \\
\hline & Soil & NP & $\mathrm{L}$ & Calcium sulphate \\
\hline P0L0C0 & 100 & 0 & 0 & 0 \\
\hline P0L4C0 & 96 & 0 & 4 & 0 \\
\hline P0L8C0 & 92 & 0 & 8 & 0 \\
\hline $\mathrm{P} 10 \mathrm{~L} 0 \mathrm{C} 0$ & 90 & 10 & 0 & 0 \\
\hline P20L0C0 & 80 & 20 & 0 & 0 \\
\hline $\mathrm{P} 10 \mathrm{~L} 4 \mathrm{C} 0$ & 86 & 10 & 4 & 0 \\
\hline $\mathrm{P} 20 \mathrm{~L} 4 \mathrm{C} 0$ & 76 & 20 & 4 & 0 \\
\hline $\mathrm{P} 10 \mathrm{~L} 8 \mathrm{C} 0$ & 82 & 10 & 8 & 0 \\
\hline P20L8C0 & 72 & 20 & 8 & 0 \\
\hline P0L0C2 & 98 & 0 & 0 & 2 \\
\hline P0L4C2 & 94 & 0 & 4 & 2 \\
\hline P0L8C2 & 90 & 0 & 8 & 2 \\
\hline P10L0C2 & 88 & 10 & 0 & 2 \\
\hline P20L0C2 & 78 & 20 & 0 & 2 \\
\hline $\mathrm{P} 10 \mathrm{~L} 4 \mathrm{C} 2$ & 84 & 10 & 4 & 2 \\
\hline P20L4C2 & 74 & 20 & 4 & 2 \\
\hline P10L8C2 & 80 & 10 & 8 & 2 \\
\hline P20L8C2 & 70 & 20 & 8 & 2 \\
\hline P0L0C4 & 96 & 0 & 0 & 4 \\
\hline P0L4C4 & 92 & 0 & 4 & 4 \\
\hline P0L8C4 & 88 & 0 & 8 & 4 \\
\hline P10L0C4 & 86 & 10 & 0 & 4 \\
\hline P20L0C4 & 76 & 20 & 0 & 4 \\
\hline P10L4C4 & 82 & 10 & 4 & 4 \\
\hline P20L4C4 & 72 & 20 & 4 & 4 \\
\hline P10L8C4 & 78 & 10 & 8 & 4 \\
\hline P20L8C4 & 68 & 20 & 8 & 4 \\
\hline P0L0C6 & 94 & 0 & 0 & 6 \\
\hline P0L4C6 & 90 & 0 & 4 & 6 \\
\hline P0L8C6 & 86 & 0 & 8 & 6 \\
\hline P10L0C6 & 84 & 10 & 0 & 6 \\
\hline P20L0C6 & 74 & 20 & 0 & 6 \\
\hline P10L4C6 & 80 & 10 & 4 & 6 \\
\hline P20L4C6 & 70 & 20 & 4 & 6 \\
\hline P10L8C6 & 76 & 10 & 8 & 6 \\
\hline P20L8C6 & 66 & 20 & 8 & 6 \\
\hline
\end{tabular}

\subsection{Unconfined Compressive Strength Test}

The UCS tests were performed according to ASTM D2166 [24] and were conducted on untreated and treated soil samples. The specimens were prepared with or without $\mathrm{CaSO}_{4} \cdot 2 \mathrm{H}_{2} \mathrm{O}$ by compaction at the maximum dry unit weight and optimum moisture content deduced of compaction tests. 


\subsection{Samples Preparation}

\subsubsection{Soil-L, soil-NP and soil-L-NP mixtures}

For both Atterberg limits and UCS tests the air dried soils were initially mixed with the predetermined quantity of NP $(0$, 10 and $20 \%), \mathrm{L}(0,4$ and $8 \%$ ) or L-NP in a dry state. On the one hand, the distilled water was added to the soil mixture for the Atterberg limits test. To let the water invades and permeates through the soil mixture, the samples are preserved in the airtight container for about 1,15 and 30 days of curing prior to testing. After curing, the paste obtained was remixed again with each stabilizer thoroughly for at least $15 \mathrm{~min}$ before performing the first test (Fig. 2).

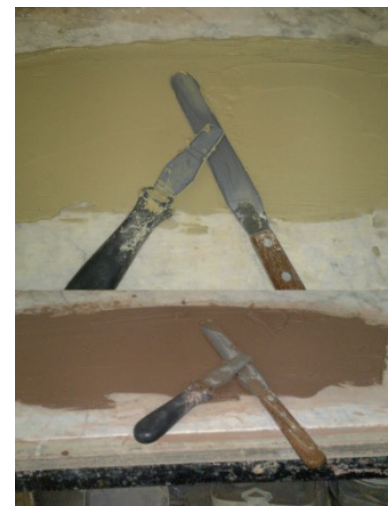

(a)

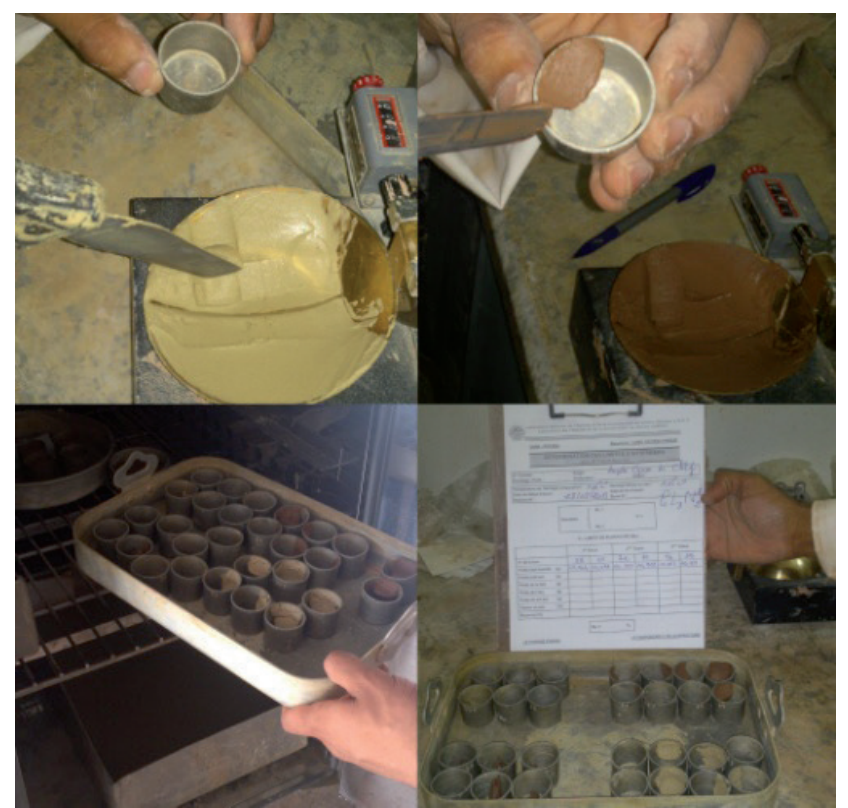

(c)

Fig. 2 Determination of the LL after 1 and 30 days of curing; (a) the paste was remixed with each stabilizer for at least $15 \mathrm{~min}$ before performing the first test, (b) practice the groove and start the test and (c) determination of the water content (LL) by desiccation at $105^{\circ} \mathrm{c}$ during 1 day

The PL tests were performed on material prepared for the liquid limit (LL) test (Fig. 3). The plastic limit (PL) was determined as the average of the two water contents. Both LL and PL tests were conducted at room temperature. The plastic index (PI) value is the difference between the LL and PL.
On the other hand, the calculated water was added to the soil mixture for the UCS test. The samples are preserved in the airtight container for about 1 hour of curing prior to the preparation of specimens by static compaction using static press. Indeed, the obtained specimens were prepared by compaction at the maximum dry unit weight and optimum moisture content deduced of compaction tests. The specimens were stored in plastic boxes to prevent possible loss of moisture which they were kept in the laboratory at the temperature of $25^{\circ} \mathrm{c}$ and the relative humidity of $50 \%$ (Fig. 4). Furthermore, after 7 to 120 days of curing the specimens are tested (Fig. 5). The tests of all samples were repeated on three identical specimens and the peak stress accepted was an average of three tests carried out on each sample type.

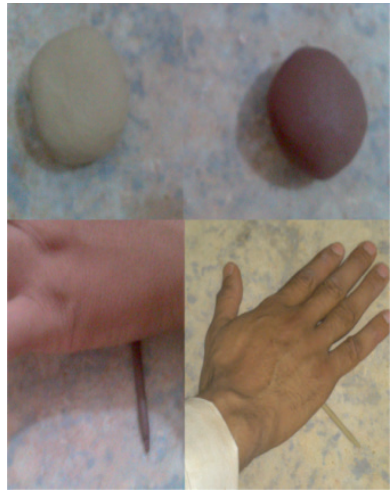

(a)

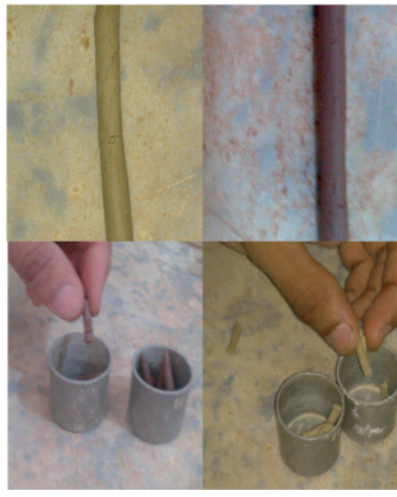

(b)

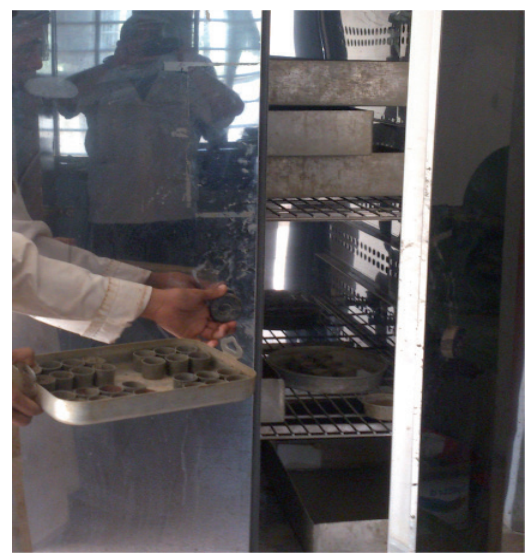

(c)

Fig. 3 Determination of the PL after 1 and 30 days of curing, (a) the roll of the soil was performed and the test must be stopped when the roll of the soil tested was cracked at $3 \mathrm{~mm}$ in diameter, (b) sample collection and (c) determination of the water content (PL) by desiccation at $105^{\circ} \mathrm{c}$ during 1 day

\subsubsection{Soil-L-sulphate, soil-NP-sulphate and soil-L- NP-sulphate mixtures}

For both Atterberg limits and UCS tests the samples were mixed in the same way as presented above except that different contents of $\mathrm{CaSO}_{4} \cdot 2 \mathrm{H}_{2} \mathrm{O}$ powder ( $0-6 \%$ by weight of dry soil) were also added into the soil-L, soil-NP and soil-L-NP mixtures in a dry state. In addition, when the water (distilled water is necessary for Atterberg limits) was added to the mixtures the Atterberg limits and UCS tests were performed after the same curing periods in the same way as presented above. 


\section{Results and Discussion}

\subsection{Atterberg Limits}

\subsubsection{Variation of liquid limit in the absence of $\mathrm{CaSO}_{4} \cdot 2 \mathrm{H}_{2} \mathrm{O}$}

Tables 6 and 7 show that the LL of both GS and RS samples decreases with increasing $\mathrm{L}$ content but increases with curing period whereby the LL of the GS appears to be still constant with time. e.g., Table 6 shows that the addition of $8 \% \mathrm{~L}$ to the GS the LL decreases from $82.8 \%$ to 62.1 and $61 \%$ after curing for 1 and 30 days, respectively. The decrease in LL can be assigned to the cation exchange brought about in the soil by the divalent calcium ions from L [8].

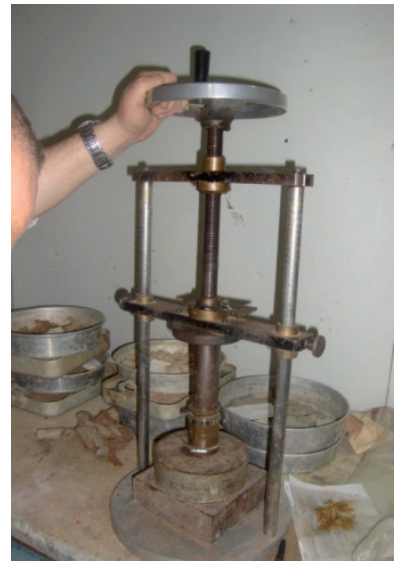

(a)

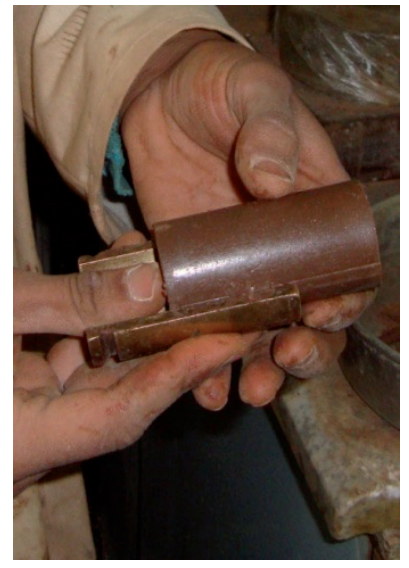

(b)

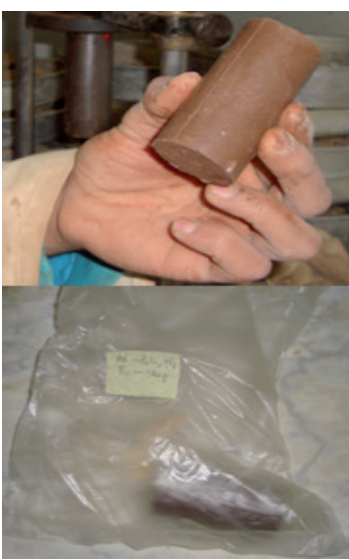

(c)

Fig. 4 Preparation of specimens by static compaction, (a) compaction of the sample at the maximum dry unit weight and optimum moisture content deduced of compaction tests, (b) demolding of the sample and (c) preservation of the compacted specimen in plastic boxes to prevent possible loss of moisture during 7 and 120 days of curing

From Table 7, the addition of $8 \% \mathrm{~L}$ to the RS increases the LL from $46.5 \%$ up to 54.9 and $59.6 \%$ after curing for 1 and 30 days, respectively. For the same class soil, Yong and Ouhadi [25] observed that with $10 \% \mathrm{~L}$ as an additive the LL increases from $49.6 \%$ up to 56.5 and $75 \%$ after curing for 1 and 30 days, respectively. A similar observation was reported by Asgari et al. [4]. On the other hand, for a similar class soil, Afès and Didier [2] found that with $6 \% \mathrm{~L}$ as an additive the LL reduces from $47.7 \%$ to 42.7 and $42.4 \%$ after curing for 7 and 30 days, respectively. The increases and decreases in Atterberg's limits depend on the mineralogical composition of soil where the Table 3 shows that the RS and GS have 0 and 20\% of montmorillonitic clay, respectively. Attoh-Okine [26] reported that decreases in the LL are observed for soils with montmorillonitic clay but increases are observed for soils with kaolinitic clay. In addition, Goswami and Singh [8] indicated that the particle arrangement and the presence of divalent cations promote flocculation and increase the LL of kaolinitic soils. Thus, the different complexes cation exchange in each of these soils (GS and RS) is reflected by the difference in their LL behavior.

Tables 6 and 7 show that the LL of both GS and RS samples decreases with increasing NP content but appears to be still constant with curing period whereby GS has the best results. e.g., the addition of $20 \% \mathrm{~L}$ to the GS decreases the LL from $82.8 \%$ to 67.3 and $66.7 \%$ after curing for 1 and 30 days, respectively. It should be noted that the addition of NP to both GS and RS samples shows a slight decrease in the LL compared with the addition of $\mathrm{L}$ alone. This is probably due to the low free L content in the NP. However, for the RS stabilized with $20 \% \mathrm{NP}$, the LL reduces from $46.5 \%$ to 39.3 and $41.2 \%$ after curing for 1 and 30 days, respectively (Table 7). For the same class soil, Sivrikaya et al. [27] observed that the LL decreases from $28 \%$ to $25 \%$ for the addition of $20 \%$ of ground granulated blast-furnace slag-A. In contrast, for the same class soil, the use of $20 \%$ rice husk ash, Basha et al. [6] and Rahman [5] reported that the LL increases from $49.8 \%$ up to $54.3 \%$ and from $36.8 \%$ up to $47 \%$, respectively.

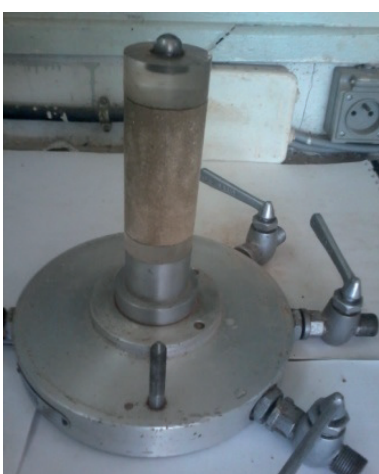

(a)

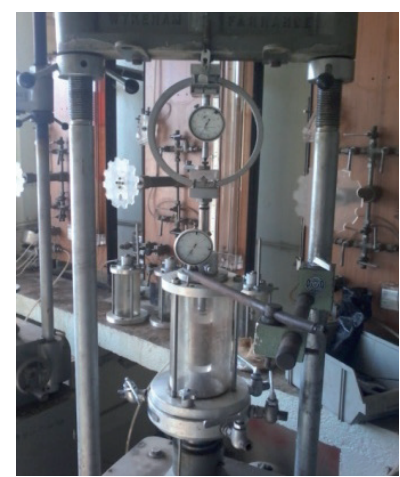

(c)

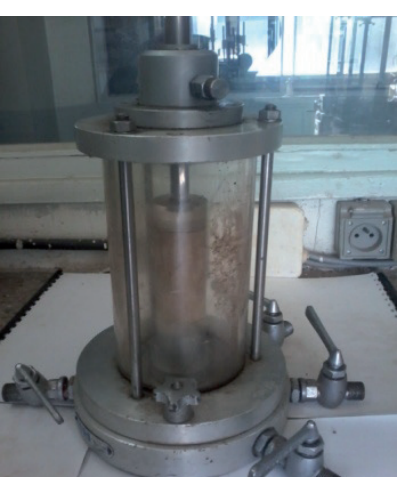

(b)

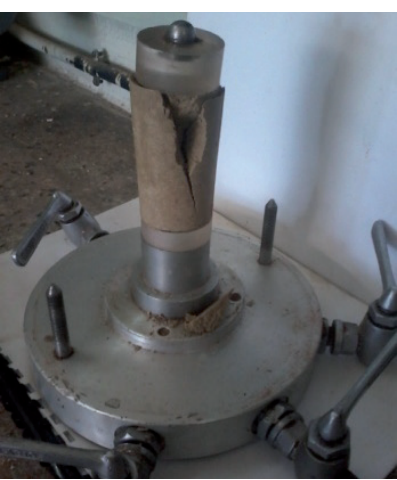

(d)
Fig. 5 Procedure of the UCS test, (a) specimen for submit the UCS test, (b) installation of the specimen in the cell, (c) installation of the cell in the static press and start the UCS test and (d) specimen state after the test 
Table 6 Effect of different content of $\mathrm{CaSO}_{4} \cdot 2 \mathrm{H}_{2} \mathrm{O}$ on the LL and PL of stabilized GS at different curing period

\begin{tabular}{|c|c|c|c|c|c|c|c|c|c|c|c|}
\hline \multirow{2}{*}{$\mathrm{AL}^{*}(\%)$} & \multirow{2}{*}{$\mathrm{Ca}^{* *}(\%)$} & \multirow{2}{*}{ DTC (day) } & \multicolumn{9}{|c|}{ Sample mixture $(\%)$} \\
\hline & & & P0L0 & P0L4 & P0L8 & P10L0 & P20L0 & P10L4 & P10L8 & P20L4 & P20L8 \\
\hline \multirow{12}{*}{ LL } & \multirow{3}{*}{0} & 1 & 82.8 & 64.5 & 62.1 & 69.4 & 67.3 & 65.2 & 63.9 & 63.0 & 62.2 \\
\hline & & 15 & 82.5 & 63.7 & 61.4 & 70.5 & 68.1 & 63.8 & 62.3 & 63.2 & 61.2 \\
\hline & & 30 & 83.2 & 63.0 & 61.0 & 68.2 & 66.7 & 62.8 & 61.2 & 62.1 & 61.0 \\
\hline & \multirow{3}{*}{2} & 1 & 73.5 & 63.8 & 61.4 & 60.6 & 58.4 & 64.4 & 62.2 & 63.2 & 61.5 \\
\hline & & 15 & 65.3 & 62.9 & 60.5 & 51.6 & 49.4 & 63.5 & 61.3 & 62.2 & 60.6 \\
\hline & & 30 & 62.7 & 62.4 & 60.0 & 49.1 & 46.9 & 63.0 & 60.9 & 61.8 & 60.2 \\
\hline & \multirow{3}{*}{4} & 1 & 70.4 & 62.6 & 60.3 & 58.2 & 56.1 & 63.3 & 61.2 & 62.0 & 60.4 \\
\hline & & 15 & 63.2 & 61.7 & 59.4 & 49.2 & 47.1 & 62.4 & 60.7 & 61.1 & 59.7 \\
\hline & & 30 & 60.6 & 61.2 & 58.4 & 46.7 & 44.7 & 61.9 & 59.8 & 60.6 & 59.0 \\
\hline & \multirow{3}{*}{6} & 1 & 68.1 & 61.3 & 59.5 & 57.9 & 54.7 & 62.2 & 60.1 & 60.9 & 59.6 \\
\hline & & 15 & 60.8 & 60.4 & 58.5 & 48.2 & 46.2 & 61.2 & 59.1 & 60.0 & 58.6 \\
\hline & & 30 & 57.8 & 59.9 & 58.1 & 45.0 & 43.7 & 60.8 & 58.7 & 59.5 & 58.2 \\
\hline \multirow{12}{*}{ PL } & \multirow{3}{*}{0} & 1 & 32.2 & 45.5 & 45.7 & 25.5 & 24.2 & 46.0 & 49.2 & 48.0 & 49.8 \\
\hline & & 15 & 32.1 & 44.5 & 45.8 & 26.5 & 25.0 & 46.2 & 49.3 & 50.0 & 49.7 \\
\hline & & 30 & 33.1 & 44.8 & 47.1 & 25.0 & 24.3 & 46.5 & 49.5 & 50.1 & 50.1 \\
\hline & \multirow{3}{*}{2} & 1 & 32.7 & 46.0 & 46.3 & 25.8 & 24.5 & 46.6 & 48.6 & 49.9 & 50.4 \\
\hline & & 15 & 36.0 & 46.5 & 46.7 & 28.1 & 26.7 & 47.0 & 49.1 & 50.4 & 50.9 \\
\hline & & 30 & 38.3 & 46.9 & 47.2 & 29.3 & 28.0 & 47.5 & 49.6 & 50.9 & 51.4 \\
\hline & \multirow{3}{*}{4} & 1 & 33.6 & 46.6 & 46.9 & 26.1 & 24.7 & 47.0 & 49.1 & 50.4 & 50.9 \\
\hline & & 15 & 36.9 & 47.1 & 47.3 & 28.4 & 27.0 & 47.5 & 49.6 & 50.8 & 51.4 \\
\hline & & 30 & 39.3 & 47.6 & 47.8 & 29.2 & 28.2 & 48.0 & 50.1 & 51.3 & 51.9 \\
\hline & \multirow{3}{*}{6} & 1 & 34.3 & 47.7 & 47.6 & 26.7 & 25.2 & 47.9 & 50.0 & 50.3 & 51.7 \\
\hline & & 15 & 36.6 & 48.2 & 48.1 & 28.8 & 27.4 & 50.4 & 51.5 & 52.8 & 52.2 \\
\hline & & 30 & 37.9 & 48.6 & 48.5 & 30,1 & 28.7 & 51.8 & 53.0 & 53.0 & 53.7 \\
\hline
\end{tabular}

${ }^{*}$ Atterberg Limits, ${ }^{* *} \mathrm{CaSO}_{4} \cdot 2 \mathrm{H}_{2} \mathrm{O}$

It should be noted that the stabilization of both clayey soils with a combination of L-NP shows the same decrease in LL values compared to that of the $\mathrm{L}$ alone. With $10 \% \mathrm{NP}+4 \% \mathrm{~L}$ as an additive the LL of the RS increases from $46.5 \%$ up to 56.4 and $61.8 \%$ after curing for 1 and 30 days, respectively (Table 7). Whereas, for the same class soil, with a combination of $12 \% \mathrm{FA}+3 \% \mathrm{~L}$, Ansary et al. [28] found that the LL of the soil-B decreases from $44 \%$ to $32.3 \%$.

\subsubsection{Variation of liquid limit in the presence of $\mathrm{CaSO}_{4} \cdot 2 \mathrm{H}_{2} \mathrm{O}$}

In all cases the LL, PL and PI of two stabilized clayey soils vary with the variation of the type and additive content, type and sulphate content and DTC (Tables 6 and 7 and Figs. 6 and 7). Indeed, the workability of both untreated and treated soil samples containing $\mathrm{CaSO}_{4} \cdot 2 \mathrm{H}_{2} \mathrm{O}$ is improved due to the significant reduction of their PI. Yilmaz and Civelekoglu [29] reported that with gypsum as an additive the PI of the bentonite soil decreases from $186.9 \%$ to 139.5 and $121.9 \%$ for the addition of 2.5 and $7.5 \%$ of gypsum, respectively.

With $\mathrm{L}$ as an additive the LL of both GS and RS samples containing $\mathrm{CaSO}_{4} \cdot 2 \mathrm{H}_{2} \mathrm{O}$ decreases considerably with increasing $\mathrm{CaSO}_{4} \cdot 2 \mathrm{H}_{2} \mathrm{O}$ content, L content and DTC. e.g., the addition of $8 \% \mathrm{~L}$ to the GS on curing for 1 day, the LL decreases from $62.1 \%$ to $61.4,60.3$ and $59.5 \%$ respectively with 2,4 and $6 \%$ $\mathrm{CaSO}_{4} \cdot 2 \mathrm{H}_{2} \mathrm{O}$ (Table 6). For a similar class soil, Kinuthia et al. [13] reported that the LL decreases from $73 \%$ to 71,69 and $67 \%$ respectively with 1,2 and $3 \% \mathrm{CaSO}_{4} \cdot 2 \mathrm{H}_{2} \mathrm{O}$ for $6 \% \mathrm{~L}$ addition. On the other hand, for the same class soil, Sivapullaiah et al. [15] observed that the LL increases from $68 \%$ up to 70,73 and $76 \%$ respectively with $0.5,1$ and $3 \% \mathrm{CaSO}_{4}$ for $6 \% \mathrm{~L}$ addition due to the chemical interaction between soil, $\mathrm{L}_{\text {and }} \mathrm{CaSO}_{4}$. However, for the RS stabilized with $8 \% \mathrm{~L}$ on curing for 1 day, the LL decreases from $54.9 \%$ to $54.2,53.7$ and $52 \%$ respectively with 2,4 and $6 \% \mathrm{CaSO}_{4} \cdot 2 \mathrm{H}_{2} \mathrm{O}$ (Table 7).

Tables 6 and 7 show that with NP as an additive the LL of both GS and RS samples decreases considerably with increasing NP content, $\mathrm{CaSO}_{4} \cdot 2 \mathrm{H}_{2} \mathrm{O}$ content and DTC. Indeed, the highest values of $\mathrm{LL}$ are achieved when the $\mathrm{CaSO}_{4} \cdot 2 \mathrm{H}_{2} \mathrm{O}$ content is greater than $2 \%$. However, there is a negligible change in the LL values of NP-treated GS samples on curing with $2 \% \mathrm{CaSO}_{4} \cdot 2 \mathrm{H}_{2} \mathrm{O}$ as compared with the samples without $\mathrm{CaSO}_{4} \cdot 2 \mathrm{H}_{2} \mathrm{O}$. In general, for any content of $\mathrm{CaSO}_{4} \cdot 2 \mathrm{H}_{2} \mathrm{O}$ and DTC the differences in LL values between $\mathrm{L}$ and NP as additives are more pronounced with the RS than with the GS. This is can be explained by the behaviour of the RS which has a low PI. This is can be explained by 


\begin{tabular}{|c|c|c|c|c|c|c|c|c|c|c|c|}
\hline \multirow{2}{*}{$A L^{*}(\%)$} & \multirow{2}{*}{$\mathrm{Ca}^{* * *}(\%)$} & \multirow{2}{*}{ DTC (day) } & \multicolumn{9}{|c|}{ Sample mixture (\%) } \\
\hline & & & POLO & P0L4 & P0L8 & P10L0 & P20L0 & P10L4 & P10L8 & P20L4 & P20L8 \\
\hline \multirow{12}{*}{ LL } & \multirow{3}{*}{0} & 1 & 46.5 & 57.4 & 54.9 & 44.0 & 39.3 & 56.4 & 56.4 & 55.1 & 54.9 \\
\hline & & 15 & 45.5 & 59.6 & 57.8 & 45.1 & 40.5 & 58.3 & 56.7 & 58.1 & 57.0 \\
\hline & & 30 & 46.0 & 61.5 & 59.6 & 44.8 & 41.2 & 61.8 & 58.2 & 60.5 & 58.1 \\
\hline & \multirow{3}{*}{2} & 1 & 46.0 & 57.0 & 54.2 & 43.3 & 39.1 & 55.9 & 54.9 & 55.3 & 54.3 \\
\hline & & 15 & 44.3 & 55.5 & 53.2 & 41.5 & 37.9 & 54.2 & 53.3 & 54.3 & 52.3 \\
\hline & & 30 & 44.0 & 55.3 & 53.0 & 41.3 & 37.7 & 54.5 & 53.2 & 54.5 & 52.7 \\
\hline & \multirow{3}{*}{4} & 1 & 44.8 & 55.8 & 53.7 & 42.0 & 38.5 & 54.9 & 54.0 & 54.8 & 53.7 \\
\hline & & 15 & 42.1 & 53.6 & 51.7 & 40.4 & 37.0 & 53.4 & 52.1 & 52.8 & 51.9 \\
\hline & & 30 & 41.7 & 53.7 & 51.5 & 40.1 & 36.7 & 53.0 & 51.8 & 52.6 & 51.4 \\
\hline & \multirow{3}{*}{6} & 1 & 39.9 & 54.0 & 52.0 & 37.4 & 35.8 & 53.3 & 52.0 & 52.9 & 51.7 \\
\hline & & 15 & 36.3 & 51.2 & 49.2 & 32.7 & 30.3 & 50.4 & 48.6 & 49.0 & 48.0 \\
\hline & & 30 & 35.9 & 50.8 & 48.8 & 31.4 & 29.7 & 49.0 & 48.2 & 48.6 & 47.8 \\
\hline \multirow{12}{*}{ PL } & \multirow{3}{*}{0} & 1 & 22.7 & 34.8 & 35.3 & 20.5 & 20.4 & 36.2 & 39.7 & 38.3 & 40.6 \\
\hline & & 15 & 21.5 & 38.5 & 39.5 & 21.8 & 21.5 & 39.5 & 40.5 & 43.0 & 44.3 \\
\hline & & 30 & 23.0 & 41.5 & 42.7 & 21.5 & 22.8 & 44.2 & 44.2 & 46.7 & 47.0 \\
\hline & \multirow{3}{*}{2} & 1 & 23.0 & 35.0 & 35.3 & 20.7 & 20.7 & 36.8 & 38.6 & 40.2 & 40.8 \\
\hline & & 15 & 23.6 & 35.7 & 36.2 & 21.0 & 21.1 & 37.5 & 39.4 & 41.2 & 42.0 \\
\hline & & 30 & 24.7 & 36.6 & 36.3 & 21.4 & 21.3 & 38.6 & 40.7 & 42.3 & 43.2 \\
\hline & \multirow{3}{*}{4} & 1 & 23.5 & 36.1 & 36.4 & 21.4 & 21.8 & 37.6 & 39.5 & 41.0 & 41.2 \\
\hline & & 15 & 24.2 & 36.8 & 36.9 & 21.9 & 22.7 & 38.7 & 40.7 & 42.0 & 42.4 \\
\hline & & 30 & 25.6 & 37.9 & 38.8 & 22.9 & 23.6 & 39.7 & 41.9 & 42.9 & 44.2 \\
\hline & \multirow{3}{*}{6} & 1 & 24.1 & 37.2 & 37.1 & 21.8 & 21.6 & 38.5 & 40.7 & 42.2 & 42.0 \\
\hline & & 15 & 24.5 & 37.8 & 37.7 & 22.1 & 21.9 & 39.7 & 41.3 & 42.3 & 42.4 \\
\hline & & 30 & 26.7 & 40.1 & 39.0 & 23.2 & 23.1 & 40.4 & 42.7 & 44.1 & 43.7 \\
\hline
\end{tabular}

${ }^{*}$ Atterberg Limits, ${ }^{* *} \mathrm{CaSO}_{4} \cdot 2 \mathrm{H}_{2} \mathrm{O}$

the behaviour of the RS which has a low PI.

In general, the greatest decrease in LL values is achieved when the L and NP are combined. However, with a combination of L-NP as additives, both stabilized GS and RS samples containing any content of $\mathrm{CaSO}_{4} \cdot 2 \mathrm{H}_{2} \mathrm{O}$ show a slight decrease in $\mathrm{LL}$ values compared with samples without $\mathrm{CaSO}_{4} \cdot 2 \mathrm{H}_{2} \mathrm{O}$. e.g., with $20 \% \mathrm{NP}+8 \% \mathrm{~L}$ as an additive the LL of the GS samples containing $6 \% \mathrm{CaSO}_{4} \cdot 2 \mathrm{H}_{2} \mathrm{O}$ decreases from 62.2 and $61 \%$ to 59.6 and $58.2 \%$ after 1 and 30 days of curing, respectively (Table 6). For the same combination and the same content of $\mathrm{CaSO}_{4} \cdot 2 \mathrm{H}_{2} \mathrm{O}$, the PL of the RS decreases from 54.9 and $58.1 \%$ to 51.7 and $47.8 \%$ after curing for 1 and 30 days, respectively (Table 7). The decrease in LL values with increasing $\mathrm{CaSO}_{4} \cdot 2 \mathrm{H}_{2} \mathrm{O}$ content and DTC is more pronounced in the RS than in the GS.

\subsubsection{Variation of plastic limit in the absence of $\mathrm{CaSO}_{4} \cdot 2 \mathrm{H}_{2} \mathrm{O}$}

For both stabilized GS and RS samples the PL increases with increasing $\mathrm{L}$ content and curing period. e.g., with $8 \% \mathrm{~L}$ as an additive the PL of the GS increases from $32.2 \%$ up to 43.8 and $44.8 \%$ after curing for 1 and 30 days, respectively (Table 6). A similar behaviour was observed by Rahman [5].
However, the addition of $8 \% \mathrm{~L}$ to the RS increases the PL from $22.7 \%$ up to 35.3 and $42.7 \%$ after curing for 1 and 30 days, respectively (Table 7). For a similar class soil, Afès and Didier [2] reported that the use of $6 \% \mathrm{~L}$ the PL increases from $24 \%$ up to 32.4 and $34 \%$ after curing for 7 and 30 days, respectively. Similar observations for similar class soil were reported by several researchers $[4,25,26]$. It is known that the use of L leads to the flocculation of clay particles which causes an immediate increase in PL.

In all cases there is a negligible decrease in the PL of NPtreated both GS and RS samples compared to L alone. With $10 \% \mathrm{NP}$ as an additive the PL of the GS decreases from $32.2 \%$ to 25.5 and $25 \%$ after curing for 1 and 30 days, respectively (Table 6). However, The addition of $10 \% \mathrm{NP}$ to the RS decreases the PL from $22.7 \%$ to 20.5 and $21.5 \%$ after 1 and 30 days of curing, respectively (Table 7). Dissimilar behaviours were observed by $[5,6]$. It is suggested that the decrease in the PL of both GS and RS samples is probably due to the replacement of coarser soil particles by finer NP particles.

In all cases there is a considerable increase in the PL of both clayey soils with increasing L-NP content and curing period (Tables 6 and 7). In general, for the combination L-NP, the PL shows a highest increase as compared to $\mathrm{L}$ alone. The addition 
of $20 \% \mathrm{NP}+8 \% \mathrm{~L}$ to the GS increases the PL from $32.2 \%$ up to 49.8 and $50.1 \%$ after curing for 1 and 30 days, respectively. With $20 \% \mathrm{NP}+8 \% \mathrm{~L}$ as an additive the PL of the RS increases from $22.7 \%$ up to 40.6 and $47 \%$ after curing for 1 and 30 days, respectively. For the same class soil, with a combination of $18 \% \mathrm{FA}+3 \% \mathrm{~L}$, Ansary et al. [28] observed that the PL of the soil-B increases from $25 \%$ up to $35.8 \%$.

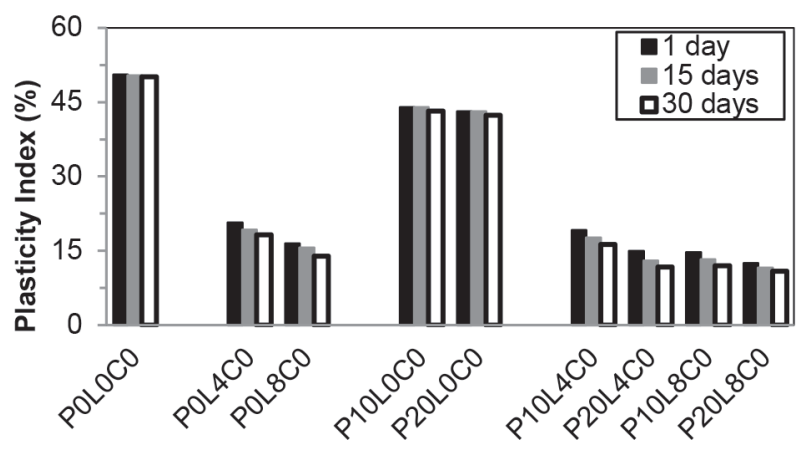

(a)

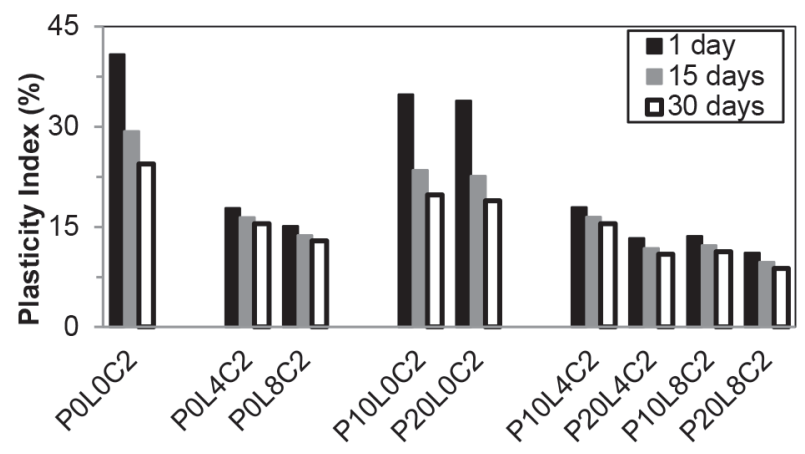

(b)

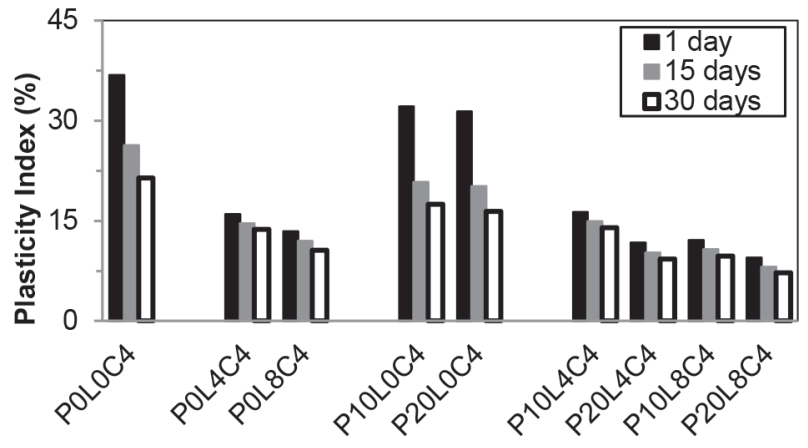

(c)

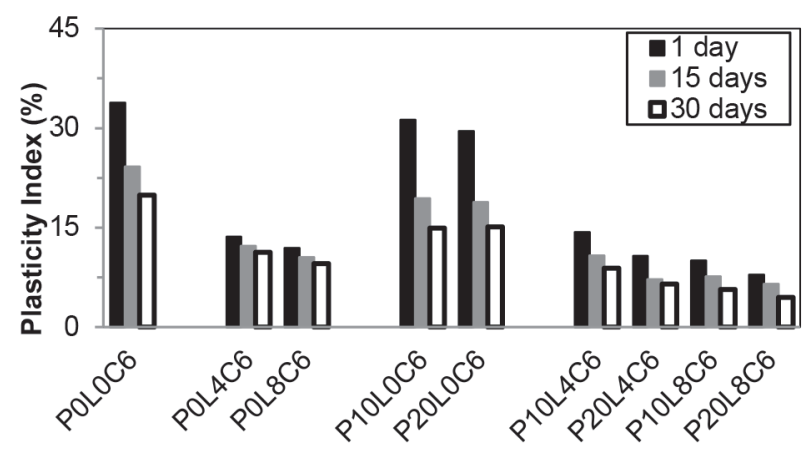

(d)

Fig 6 Effect of different content of $\mathrm{CaSO}_{4} \cdot 2 \mathrm{H}_{2} \mathrm{O}$ on the PI of the stabilized GS

\subsubsection{Variation of plastic limit in the presence of $\mathrm{CaSO}_{4} \cdot 2 \mathrm{H}_{2} \mathrm{O}$}

In all cases the PL of L-treated both GS and RS samples increases with increasing $\mathrm{CaSO}_{4} \cdot 2 \mathrm{H}_{2} \mathrm{O}$ content, $\mathrm{L}$ content and TDC. e.g., with $8 \% \mathrm{~L}$ as an additive the PL of the GS sample containing $6 \% \mathrm{CaSO}_{4} \cdot 2 \mathrm{H}_{2} \mathrm{O}$ increases from 45.7 and $47.1 \%$ up to 47.6 and $48.5 \%$ after curing for 1 and 30 days, respectively (Table 6). However, for the RS sample stabilized with $8 \% \mathrm{~L}$ in the presence of $6 \% \mathrm{CaSO}_{4} \cdot 2 \mathrm{H}_{2} \mathrm{O}$ the $\mathrm{PL}$ increases from $35.5 \%$ up to $37.1 \%$ after 1 day of curing but decreases from $42.7 \%$ to $39 \%$ after curing for 30 days (Table 7).

With any content of NP as an additive the PL of the RS increases slightly with increasing $\mathrm{CaSO}_{4} \cdot 2 \mathrm{H}_{2} \mathrm{O}$ content and DTC, whereas the PL of the GS increases with DTC but appears to be still constant with increasing $\mathrm{CaSO}_{4} \cdot 2 \mathrm{H}_{2} \mathrm{O}$ content. Generally, the effects produced by the $\mathrm{CaSO}_{4} \cdot 2 \mathrm{H}_{2} \mathrm{O}$ on the $\mathrm{PL}$ of NP-treated both GS and RS samples are negligible as compared with L alone or in combination with NP.

It is clear to see that the PL of L-NP-treated both GS and RS samples increases with increasing L-NP content, $\mathrm{CaSO}_{4} \cdot 2 \mathrm{H}_{2} \mathrm{O}$ content and DTC (Tables 6 and 7). Indeed, the addition of L-NP to the GS samples containing $\mathrm{CaSO}_{4} \cdot 2 \mathrm{H}_{2} \mathrm{O}$ shows an increase in the PL as compared with samples without $\mathrm{CaSO}_{4} \cdot 2 \mathrm{H}_{2} \mathrm{O}$. Whereas, the PL values of the RS samples treated with L-NP without $\mathrm{CaSO}_{4} \cdot 2 \mathrm{H}_{2} \mathrm{O}$ are very higher as compared with samples containing $\mathrm{CaSO}_{4} \cdot 2 \mathrm{H}_{2} \mathrm{O}$.

\subsubsection{Variation of the plasticity index in the absence of $\mathrm{CaSO}_{4} \cdot 2 \mathrm{H}_{2} \mathrm{O}$}

The changes in the PI of both GS and RS samples stabilized with L, NP and L-NP without sulphates are depicted in Figs. 6a and 7a. The addition of $\mathrm{L}$ to both GS and RS samples improves their workability due to the significant reduction in their PI. The PI of both GS and RS samples decreases with increasing L content and curing period whereby the decrease is more pronounced in the GS than the in RS. It is apparent that an addition of $8 \% \mathrm{~L}$ is sufficient to decrease the PI of the GS from 50.5 to 15.6 and $13.9 \%$ after curing for 1 and 30 days, respectively (Fig. 6a). Whereas, for the RS stabilized with the same content of L the PI decreases from $23.7 \%$ to only 19.6 and $16.9 \%$ after curing for 1 and 30 days, respectively (Fig. 7a). For the same class soil, Afès and Didier [2] reported that with $6 \% \mathrm{~L}$ as an additive the PI decreases from $23.7 \%$ to 10.3 and $8.4 \%$ after curing for 7 and 30 days, respectively. Similar observations were reported by [26, 28].

The addition of NP to both GS and RS samples reduces slightly their PI compared with L alone. It is clear to observe that with $20 \%$ NP the PI of the GS decreases from 50.5 to only 43.1 and $42.4 \%$ after curing for 1 and 30 days, respectively (Fig. 6a). However, with the same content of NP as an additive the PI of the RS decreases from $23.8 \%$ to only 18.9 and $18.4 \%$ after curing for 1 and 30 days, respectively. For the same class soil, Yadu and Tripathi [30] and Sivrikaya et al. [27] reported 
that the PI decreases from 17 and $9 \%$ to 13 and 4\% for the addition of $12 \%$ and $20 \%$ of granulated blast furnace slag and ground granulated blast furnace slag-A, respectively. Similar trends were observed by Eberemu [31] and Rahman [5] where they have used bagasse ash and rice husk ash respectively. In contrast, Degirmenci et al. [32] were found that the PI increased with increasing FA content due to its small size particles with high surface area compared with that of the NP.

The better results of PI are achieved when the combination L-NP is used. It is obvious to see that the combination L-NP has a significant effect on the PI of the GS than of the RS. In addition, there is a significant decrease in PI with increasing L-NP content and curing period. e.g., for the GS stabilized with a combination of $20 \% \mathrm{NP}+8 \% \mathrm{~L}$ the PI decreases from $50.5 \%$ to 12.5 and $10.9 \%$ after curing for 1 and 30 days, respectively (Fig. 2a and b). However, for the RS stabilized with the same combination the PI decreases from $23.8 \%$ to 14.8 and $11.1 \%$ after curing for 1 and 30 days, respectively (Fig. 7a). Ansary et al. [28] reported that for a similar class soil, the PI decreases from $19 \%$ to $2.3 \%$ for the addition of $6 \% \mathrm{FA}+3 \% \mathrm{~L}$. In all cases, the high reduction in PI is observed for samples stabilized with a combination of L-NP compared with L or NP alone. This behaviour can be explained by the complementary roles played by the L and NP where the beneficial effects of one can compensate for the disadvantages that could present another.

\subsubsection{Variation of the plasticity index in the presence of $\mathrm{CaSO}_{4} \cdot 2 \mathrm{H}_{2} \mathrm{O}$}

Figs. $2 b-d$ and $3 b-d$ show the changes in the PI of both GS and RS samples stabilized with NP, L and L-NP in the presence of varying contents of $\mathrm{CaSO}_{4} \cdot 2 \mathrm{H}_{2} \mathrm{O}$. The addition of $\mathrm{L}$ alone to both GS and RS samples on curing with $\mathrm{CaSO}_{4} \cdot 2 \mathrm{H}_{2} \mathrm{O}$ decreases considerably the PI particularly with increasing $\mathrm{CaSO}_{4} \cdot 2 \mathrm{H}_{2} \mathrm{O}$ content, $\mathrm{L}$ content and DTC. e.g., after 30 days of DTC, the PI of the GS stabilized with the same content of $\mathrm{L}$ decreases from $16.4 \%$ to $12.9,10.6$ and $9.6 \%$ respectively with 2, 4 and $6 \%$ of $\mathrm{CaSO}_{4} \cdot 2 \mathrm{H}_{2} \mathrm{O}$ (Fig. $6 \mathrm{~b}$, c and d). For the same DTC, the PI of the RS stabilized with $8 \% \mathrm{~L}$ decreases from $19.6 \%$ to $16.7,12.7$ and $9.8 \%$ in the presence of 2,4 and $6 \% \mathrm{CaSO}_{4} \cdot 2 \mathrm{H}_{2} \mathrm{O}$, respectively (Fig. $7 \mathrm{~b}$, c and d). Kinuthia et al. [13] reported that the interaction between two particles of clay soil is considerably affected by the cation exchange process because the increase in cation concentration results an increase in the distance between these clay particles, this promotes the increase of the clay particles size and affects the pores distribution due to the particles arrangement which leads to the change in the consistency limits of soils. Indeed, the modification in the PI is the result of cation exchange processes which affect the viscosity of the clay-water mix.

The PI of two stabilized clayey soils decreases with increasing NP content, DTC and $\mathrm{CaSO}_{4} \cdot 2 \mathrm{H}_{2} \mathrm{O}$ content whereby $\mathrm{RS}$ has the best results. e.g., after 1 day of DTC, the PI of the

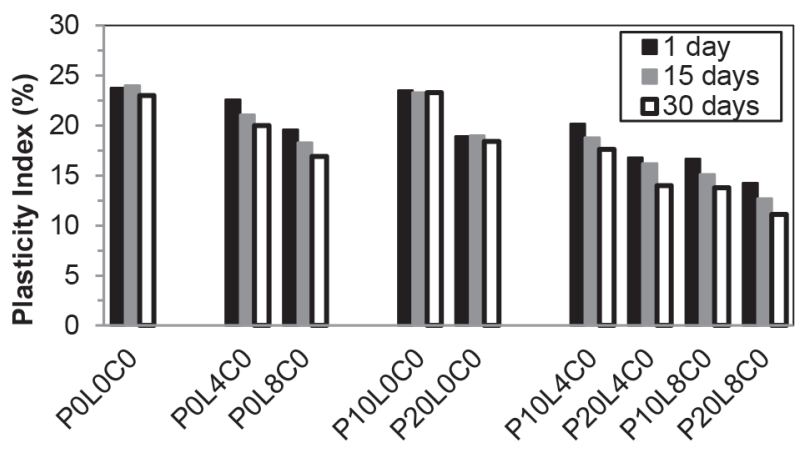

(a)

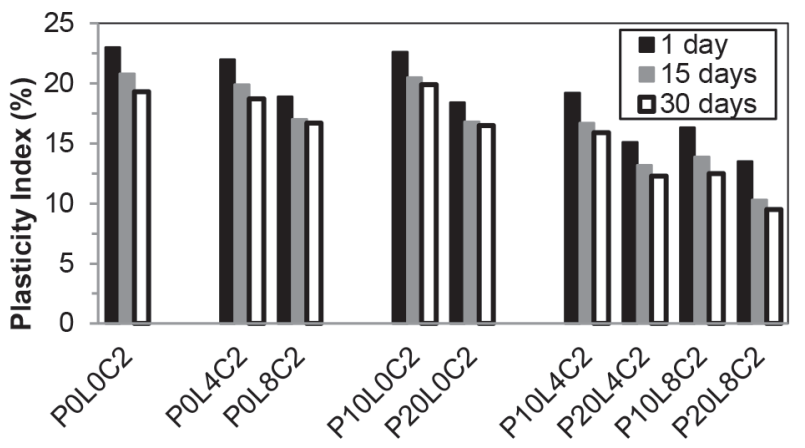

(b)

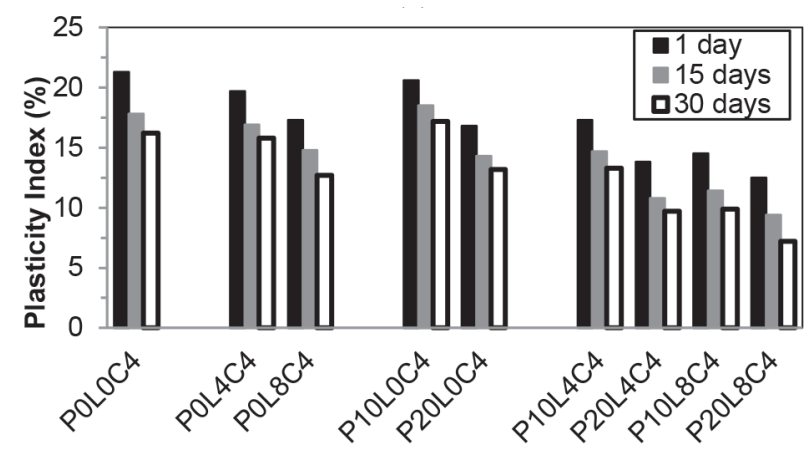

(c)

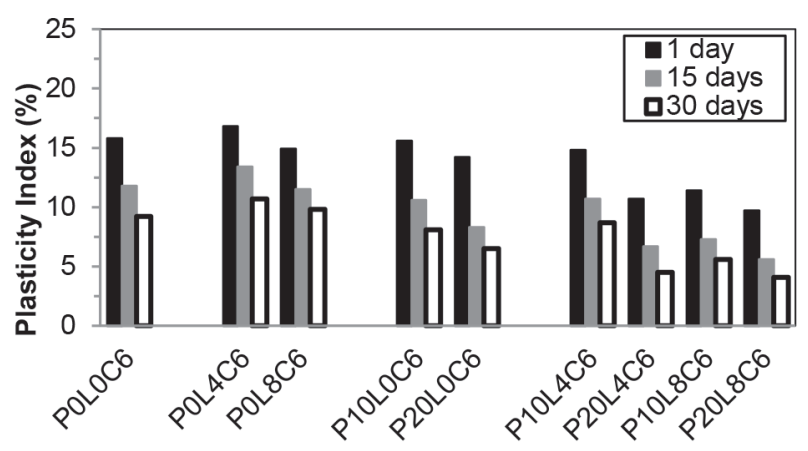

(d)

Fig. 7 Effect of different content of $\mathrm{CaSO}_{4} \cdot 2 \mathrm{H}_{2} \mathrm{O}$ on the PI of the stabilized RS

GS stabilized with $20 \%$ NP decreases from $50.5 \%$ to 33.9 and $29.5 \%$ respectively with 2 and $6 \% \mathrm{CaSO}_{4} \cdot 2 \mathrm{H}_{2} \mathrm{O}$ (Fig. $6 \mathrm{~b}$ and d). Whereas, for the same content of NP and the same DTC, the PI of the RS decreases from $23.8 \%$ to 18.4 and $14.2 \%$ respectively with 2 and $6 \% \mathrm{CaSO}_{4} \cdot 2 \mathrm{H}_{2} \mathrm{O}$ (Fig. $7 \mathrm{~b}$ and d). In addition, with $20 \% \mathrm{NP}$ as an additive and after 30 days of DTC, the PI 
of the GS decreases from $50.5 \%$ to 18.9 and $15.1 \%$ respectively with 2 and $6 \% \mathrm{CaSO}_{4} \cdot 2 \mathrm{H}_{2} \mathrm{O}$ (Fig. $6 \mathrm{~b}$ and d). Whereas, for the same content of NP and the same DTC, the PI of the RS decreases from $23.8 \%$ to 16.5 and $6.5 \%$ respectively with 2 and $6 \% \mathrm{CaSO}_{4} \cdot 2 \mathrm{H}_{2} \mathrm{O}$ (Fig. $7 \mathrm{~b}$ and d). It should be noted that the addition of NP to both GS and RS samples on curing with any content of $\mathrm{CaSO}_{4} \cdot 2 \mathrm{H}_{2} \mathrm{O}$ shows a much better decrease in the PI as compared with untreated and treated soil samples without $\mathrm{CaSO}_{4} \cdot 2 \mathrm{H}_{2} \mathrm{O}$. According to Yilmaz and Civelekoglu [29], the PI of the bentonite stabilized with gypsum decreases from $186.9 \%$ to 139.5 and $120.8 \%$ for the addition of 2.5 and $10 \%$ of gypsum, respectively. This is due to the replacement of monovalent ions by calcium ions (from $\mathrm{CaSO}_{4} \cdot 2 \mathrm{H}_{2} \mathrm{O}$ ) which provokes a reduction in diffuse double layer thickness and leads to the decrease in LL, consequently, the decrease in the PI. For comparison, it is clear to see that after curing for 30 days the RS samples containing $6 \% \mathrm{CaSO}_{4} \cdot 2 \mathrm{H}_{2} \mathrm{O}$ alone or mixed with $20 \%$ NP produces high PI values as compared with samples stabilized with $8 \% \mathrm{~L}$ alone or mixed with $6 \% \mathrm{CaSO}_{4} \cdot 2 \mathrm{H}_{2} \mathrm{O}$.

Furthermore, the best results of PI are achieved for two clayey soil samples stabilized with a combination of L-NP on curing with various content of $\mathrm{CaSO}_{4} \cdot 2 \mathrm{H}_{2} \mathrm{O}$. Moreover, there is a significant decrease in the PI of both GS and RS samples with increasing $\mathrm{CaSO}_{4} \cdot 2 \mathrm{H}_{2} \mathrm{O}$ content and DTC (Figs. 6b-d and $7 \mathrm{~b}-\mathrm{d})$. e.g., for the GS stabilized with $10 \% \mathrm{NP}+4 \% \mathrm{~L}$ on curing for 1 day of DTC, the PI decreases from $19.2 \%$ to $17.9,16.3$ and $14.3 \%$ respectively with 2,4 and $6 \% \mathrm{CaSO}_{4} \cdot 2 \mathrm{H}_{2} \mathrm{O}$ (Fig. $6 \mathrm{~b}$, $\mathrm{c}$ and d). Whereas for the same soil and after 30 days of DTC, the PI decreases from $16.3 \%$ to $15.5,14$ and $8.9 \%$ respectively with 2, 4 and $6 \% \mathrm{CaSO}_{4} \cdot 2 \mathrm{H}_{2} \mathrm{O}$ (Fig. $6 \mathrm{~b}$, c and d). In addition, the decrease in the PI of both GS and RS samples with increasing $\mathrm{CaSO}_{4} \cdot 2 \mathrm{H}_{2} \mathrm{O}$ content and DTC is considerably important when the content of L-NP increases. e.g., for the GS stabilized with $20 \% \mathrm{NP}+8 \% \mathrm{~L}$ on curing for 1 day of DTC, the PI decreases from $12.5 \%$ to $11.1,9.5$ and $7.9 \%$ respectively with 2,4 and $6 \% \mathrm{CaSO}_{4} \cdot 2 \mathrm{H}_{2} \mathrm{O}$ (Fig. 6b, c and d). Whereas for the same soil and after 30 days of DTC, the PI decreases from $10.9 \%$ to 8.8 , 7.2 and $4.5 \%$ respectively with 2,4 and $6 \% \mathrm{CaSO}_{4} \cdot 2 \mathrm{H}_{2} \mathrm{O}$ (Fig. $6 \mathrm{~b}, \mathrm{c}$ and d). In general, the PI values of L-NP-treated both GS and RS samples containing any content of $\mathrm{CaSO}_{4} \cdot 2 \mathrm{H}_{2} \mathrm{O}$ are very higher compared with samples without $\mathrm{CaSO}_{4} \cdot 2 \mathrm{H}_{2} \mathrm{O}$.

Generally, the improvment in the consistency limits of two stabilized clayey soils depends on the type and the content of additive added, the content of sulphate used, the DTC and the mineralogical composition of stabilized soil.

\subsection{Unconfined Compressive Strength 4.2.1 Variation of the unconfined compressive strength in the absence of sulphates}

Figures 8-10 depict the results of the effect of L, NP and their combinations on the UCS of both GS and RS samples stabilized with or without $\mathrm{CaSO}_{4} \cdot 2 \mathrm{H}_{2} \mathrm{O}$. According to Figs. $8 \mathrm{a}$ and 9a, the addition of $\mathrm{L}$ alone to both GS and RS samples binds their particles and produces a significant increase in the UCS which increases with increasing L content and curing period. A similar behaviour was observed by McCarthy et al. [33]. In addition, Asgari et al. [4] reported that the UCS of the soil obtained from northwestern of Arak city increases curing period and L content up to $3 \%$ but decreases after this content. The increase in strength is due to the formation of cementing compounds binding the soil particles which is the result of the $\mathrm{L}$ reaction with the clay particles [22]. However, there is a negligible increase in UCS values of both GS and RS samples when the NP is used alone due to its low reactivity with the clay particles. Therefore, it is not possible to use the NP alone for the stabilization of these clayey soils. The differences in the UCS between L and NP as additives are more pronounced with the RS than with the GS. This behaviour is probably due to the mineralogical composition and high plasticity index value of the GS as compared with that of the RS.

The results of the effect produced by the combination L-NP without $\mathrm{CaSO}_{4} \cdot 2 \mathrm{H}_{2} \mathrm{O}$ on the UCS of both GS and RS samples are depicted in Fig. 10a. It can be seen that the better results of the UCS are achieved when the combination L-NP is used. However, the UCS of both stabilized clayey soils increases considerably with curing period and L-NP content. E.g., the UCS of the GS stabilized with a combination of $20 \% \mathrm{NP}+4 \% \mathrm{~L}$ increases from 0.1 $\mathrm{MPa}$ up to 1.3 and $3 \mathrm{MPa}$ after curing for 7 and 120 days, respectively. For a similar class soil, McCarthy et al. [33] reported that the UCS of oxford clay treated with a combination of $18 \% \mathrm{FA}+3 \% \mathrm{~L}$ increases from $0.4 \mathrm{MPa}$ up to 1 and $1.8 \mathrm{MPa}$ after curing for 7 and 90 days, respectively. For the RS stabilized with a combination of $20 \% \mathrm{NP}+4 \% \mathrm{~L}$ the UCS increases from 0.5 $\mathrm{MPa}$ up to 2.2 and $7 \mathrm{MPa}$ after curing for 7 and 120 days, respectively. For a similar class soil, McCarthy et al. [33] reported that the UCS of Lias clay treated with a combination of $18 \% \mathrm{FA}+3 \% \mathrm{~L}$ increases from $0.4 \mathrm{MPa}$ up to 1.1 and 2.1 MPa after curing for 7 and 90 days, respectively. 


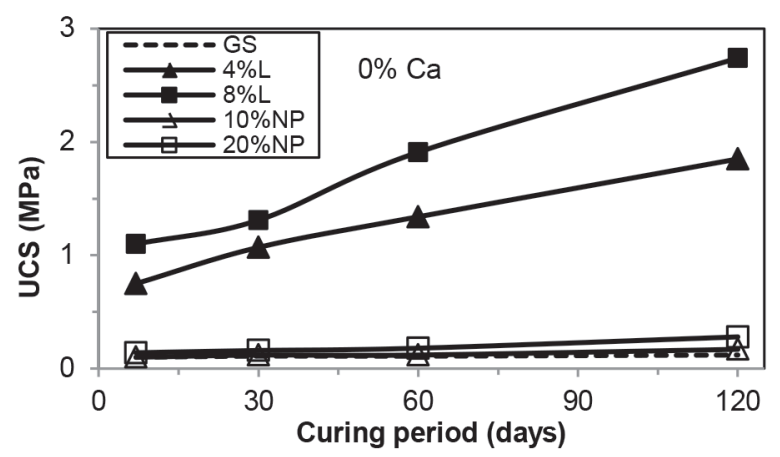

(a)

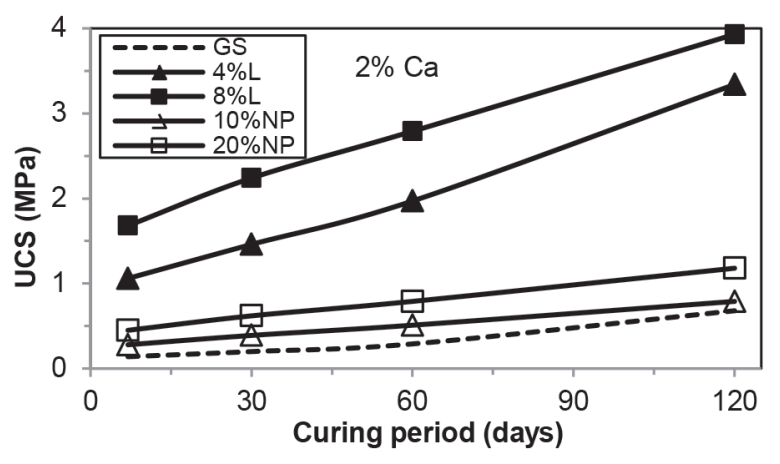

(b)

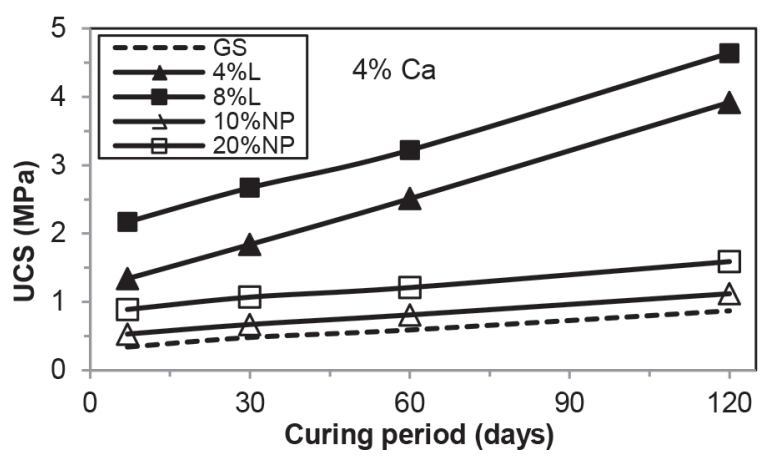

(c)

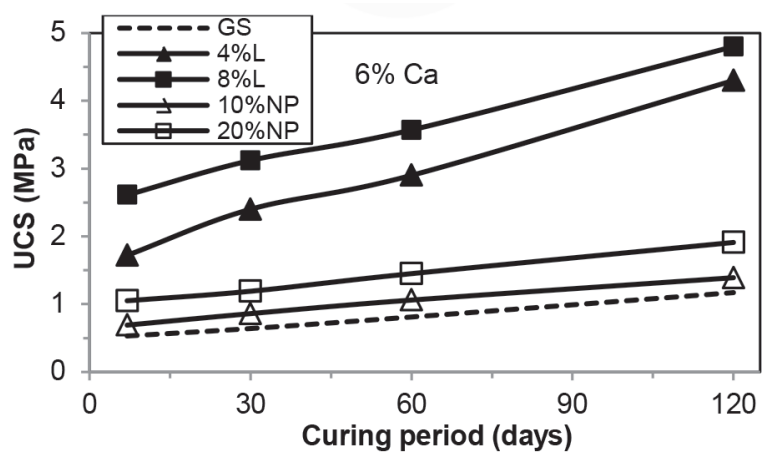

(d)

Fig. 8 Effect of different content of $\mathrm{CaSO}_{4} \cdot 2 \mathrm{H}_{2} \mathrm{O}$ on the UCS of the GS stabilized with L and NP alone

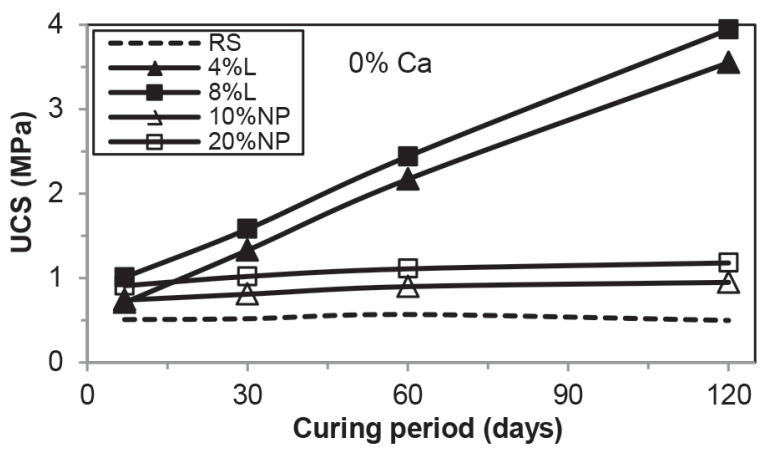

(a)

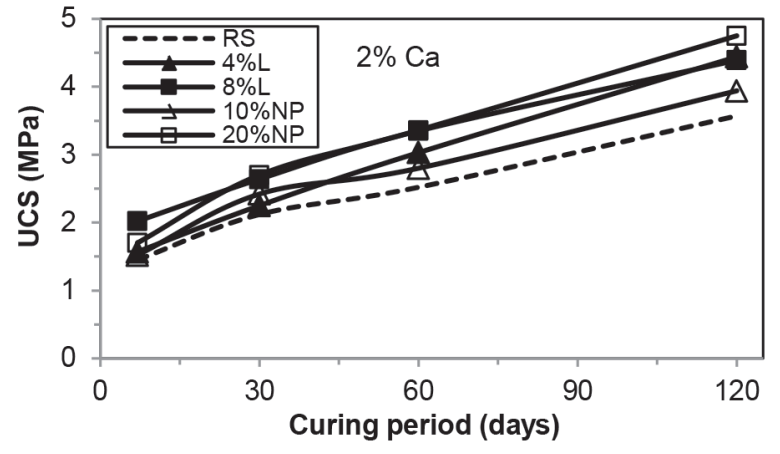

(b)

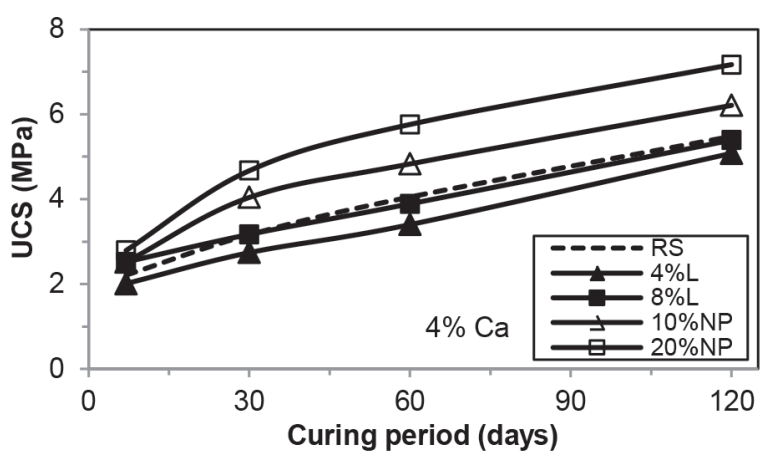

(c)

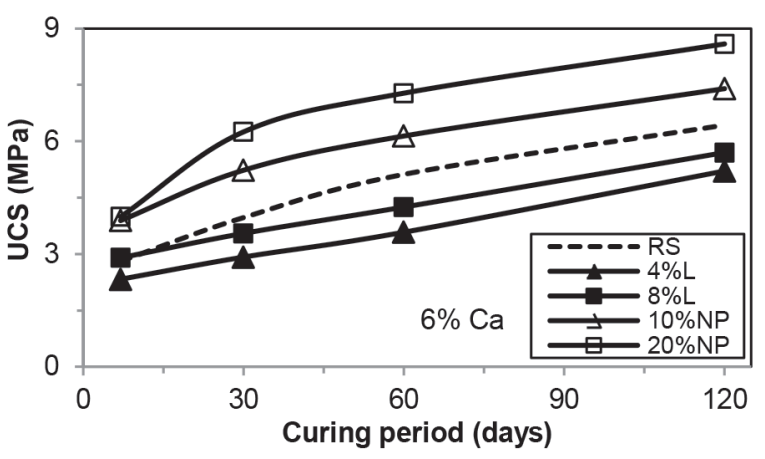

(d)

Fig. 9 Effect of different content of $\mathrm{CaSO}_{4} \cdot 2 \mathrm{H}_{2} \mathrm{O}$ on the UCS of the RS stabilized with L and NP alone 


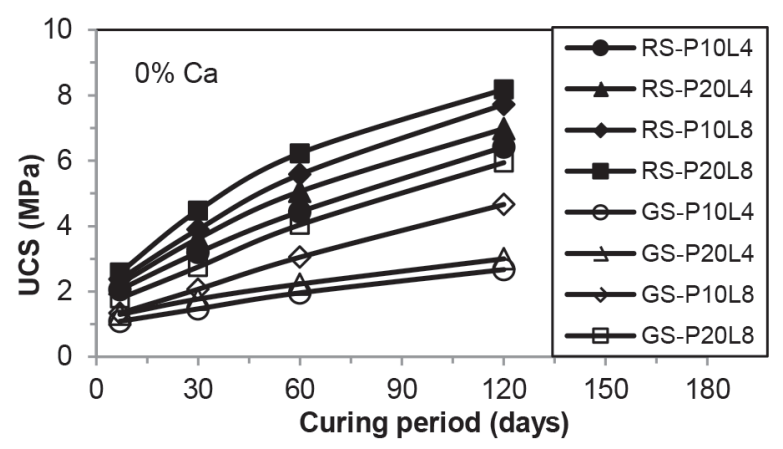

(a)

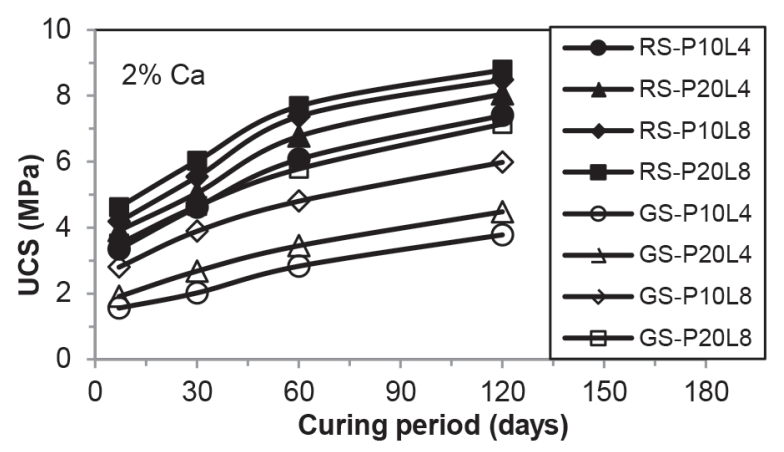

(b)

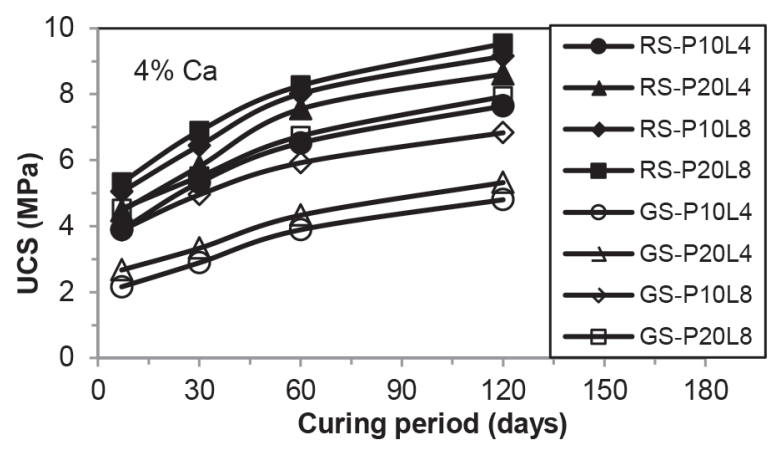

(c)

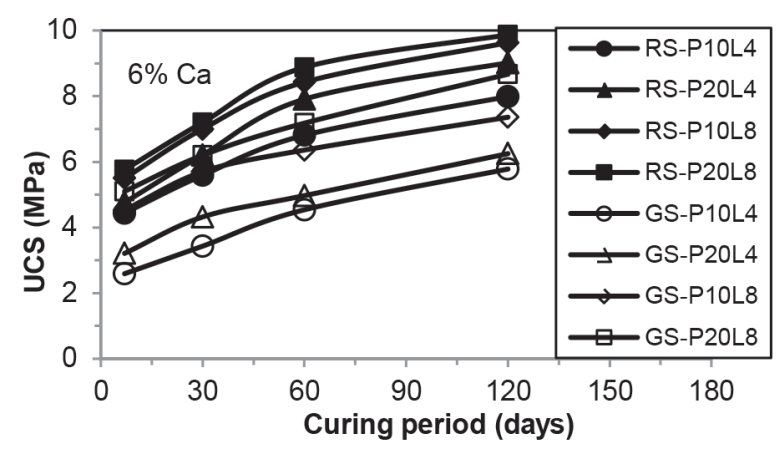

(d)

Fig. 10 Effect of different content of $\mathrm{CaSO}_{4} \cdot 2 \mathrm{H}_{2} \mathrm{O}$ on the UCS of two soils stabilized with L-NP

However, it is obvious to observe that the combination L-NP has a much better effect on the UCS of the RS than of the GS, particularly, at later stage. e.g., after curing for 120 days the UCS of both GS and RS stabilized with a combination of $20 \% \mathrm{NP}+8 \% \mathrm{~L}$ represented an increase of 47 and 16 times respectively compared with both untreated soils. Similar observations were reported by Hossain et al. [9] where they found that the combination of $10 \%$ volcanic ash and $4 \%$ L for both S1 and S2 soils represented an increase of 21 and 10 times respectively compared with both untreated soils. The dissolution of alumina and silica from soil and/or NP depends strongly on the L content which produces more cementitious products responsible on the increase in the UCS of both GS and RS samples. In all cases, high UCS values are observed for samples stabilized with a combination of L-NP compared to those stabilized with L or NP alone. The same behaviour is observed by Kolias et al. [1]. Generally, the better increase produced by the L alone or by a combination of L-NP on the UCS of both clayey soils can be explained by the pozzolanic reactions which form new cementing compounds and bind the soil particles together [21].

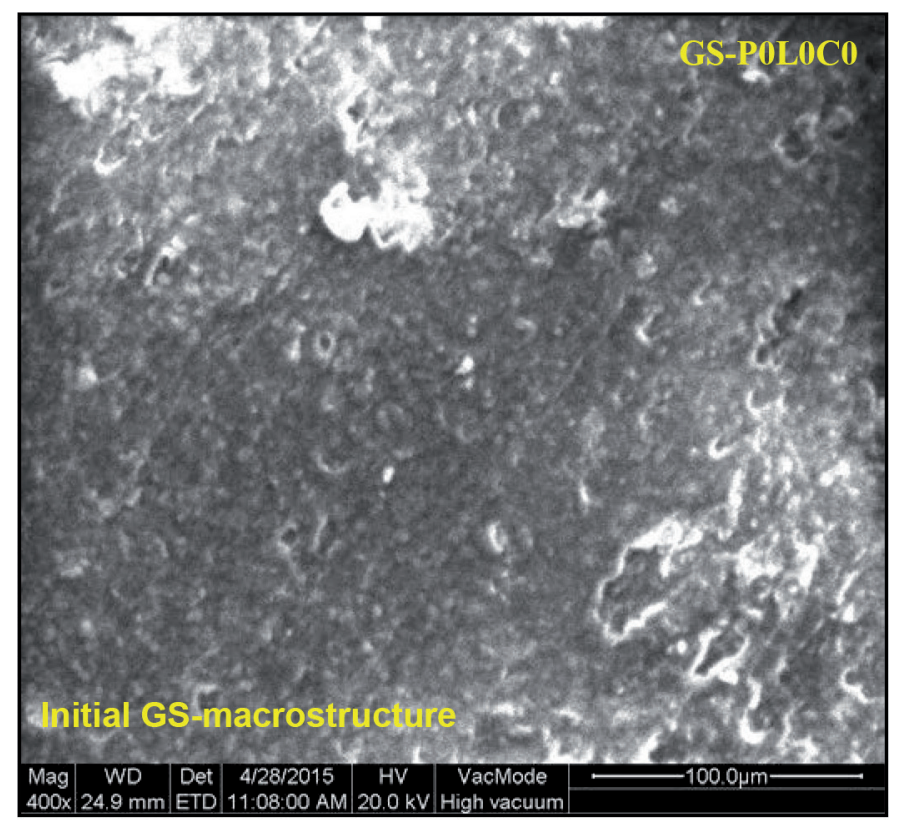

(a)

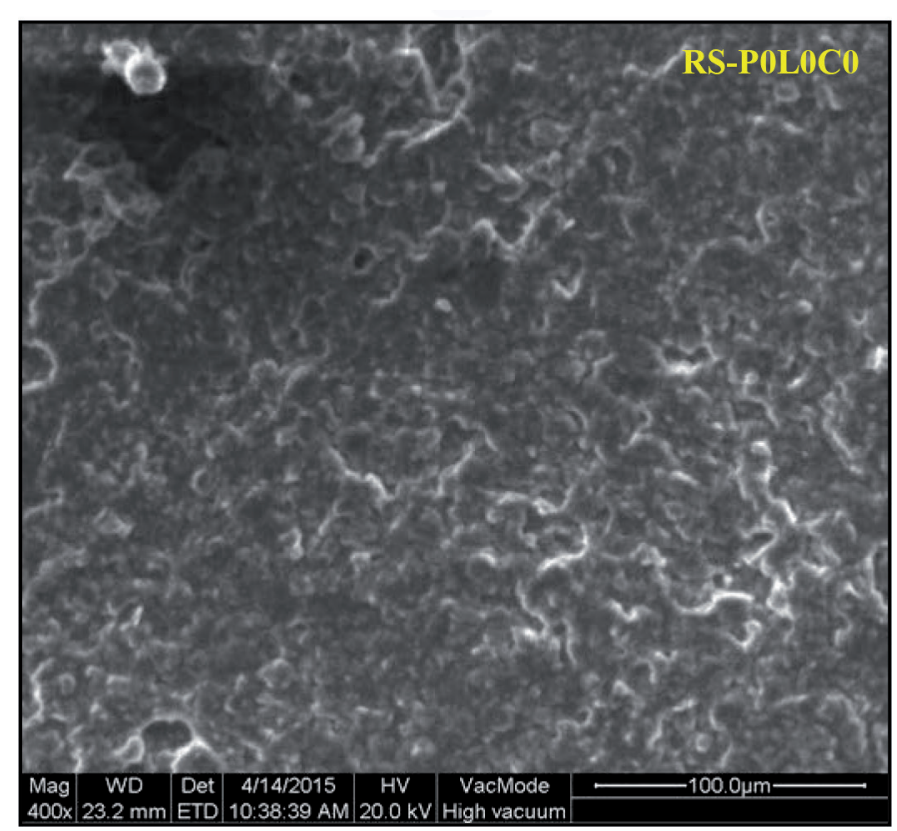

(b)

Fig. 11 SEM images show the intial microstructure of both untreated GS and $\mathrm{RS}$ samples without $\mathrm{CaSO}_{4} \cdot 2 \mathrm{H}_{2} \mathrm{O}$ after 60 days of curing 


\subsubsection{Variation of the unconfined compressive strength in the presence of sulphates}

The results of the effect of L, NP and their combination in the presence of $\mathrm{CaSO}_{4} \cdot 2 \mathrm{H}_{2} \mathrm{O}$ on the UCS of both stabilized GS and RS samples are depicted in Figs. 8b-d and 9b-d. In all cases the UCS values of both GS and RS samples stabilized with L, $\mathrm{NP}$ and L-NP in the presence of $\mathrm{CaSO}_{4} \cdot 2 \mathrm{H}_{2} \mathrm{O}$ are higher than those of samples without $\mathrm{CaSO}_{4} \cdot 2 \mathrm{H}_{2} \mathrm{O}$.

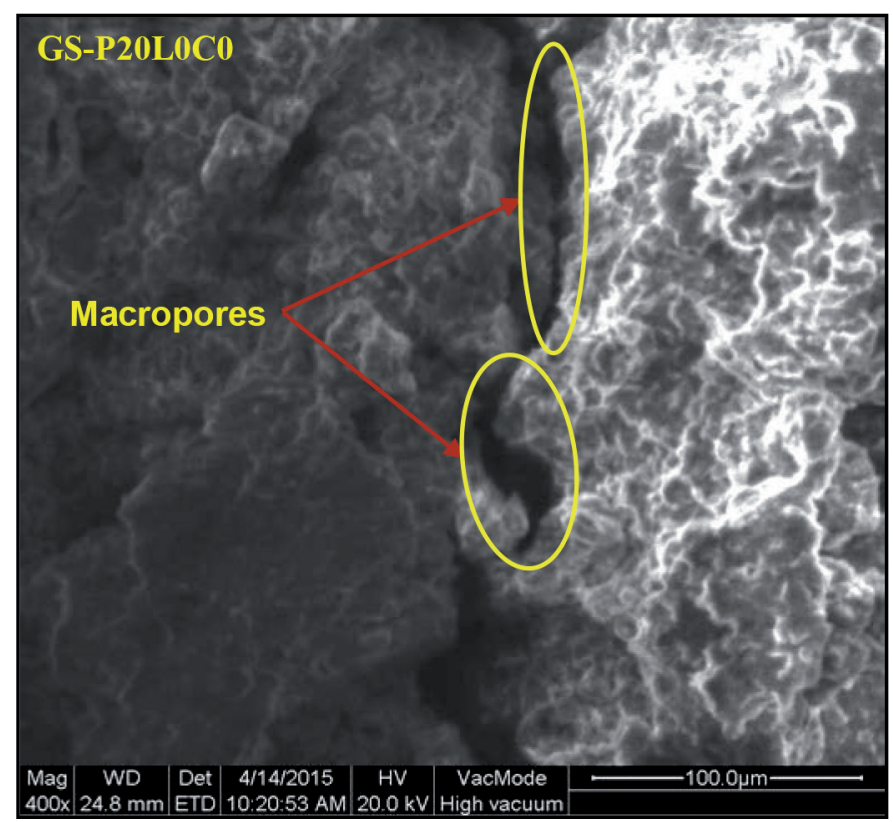

(a)

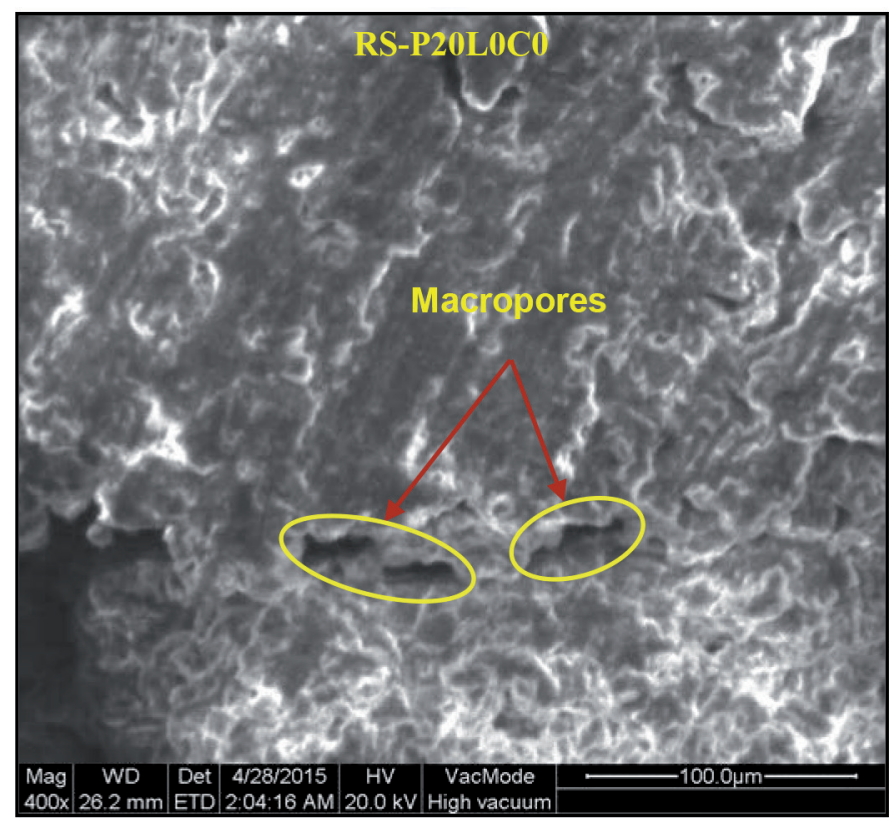

(b)

Fig. 12 SEM images show the evolution of the microstructure of NP-treated both GS and RS samples without $\mathrm{CaSO}_{4} \cdot 2 \mathrm{H}_{2} \mathrm{O}$ after 60 days of curing

Indeed, there is a significant increase in UCS of both untreated GS and RS samples with increasing $\mathrm{CaSO}_{4} \cdot 2 \mathrm{H}_{2} \mathrm{O}$ content and curing period whereby RS has the best results. Yilmaz and Civelekoglu [29] observed that with gypsum as an additive the UCS of the bentonite soil increases from $58.7 \mathrm{KPa}$ up to 73.1 and $79.6 \mathrm{KPa}$ for the addition of 2.5 and $7.5 \%$ of gypsum, respectively. It is obvious to see that there is a much better increase in UCS values of NP-treated both GS and RS samples with increasing $\mathrm{CaSO}_{4} \cdot 2 \mathrm{H}_{2} \mathrm{O}$ content and curing period whereby $\mathrm{RS}$ has the greatest values. E.g., with $20 \% \mathrm{NP}$ as an additive, after 7 days of curing the UCS of the GS increases from $0.2 \mathrm{MPa}$ up to 0.5 and $1.1 \mathrm{MPa}$ respectively with 2 and $6 \% \mathrm{CaSO}_{4} \cdot 2 \mathrm{H}_{2} \mathrm{O}$. But, for the same content of NP and curing period the UCS of the RS increases from $0.9 \mathrm{MPa}$ up to 1.7 and $4 \mathrm{MPa}$ respectively with 2 and $6 \% \mathrm{CaSO}_{4} \cdot 2 \mathrm{H}_{2} \mathrm{O}$. However, with $20 \% \mathrm{NP}$ as an additive, after 120 days of curing the UCS of the GS increases from 0.3 MPa up to only 1.2 and $1.9 \mathrm{MPa}$ respectively with 2 and $6 \% \mathrm{CaSO}_{4} .2 \mathrm{H}_{2} \mathrm{O}$.

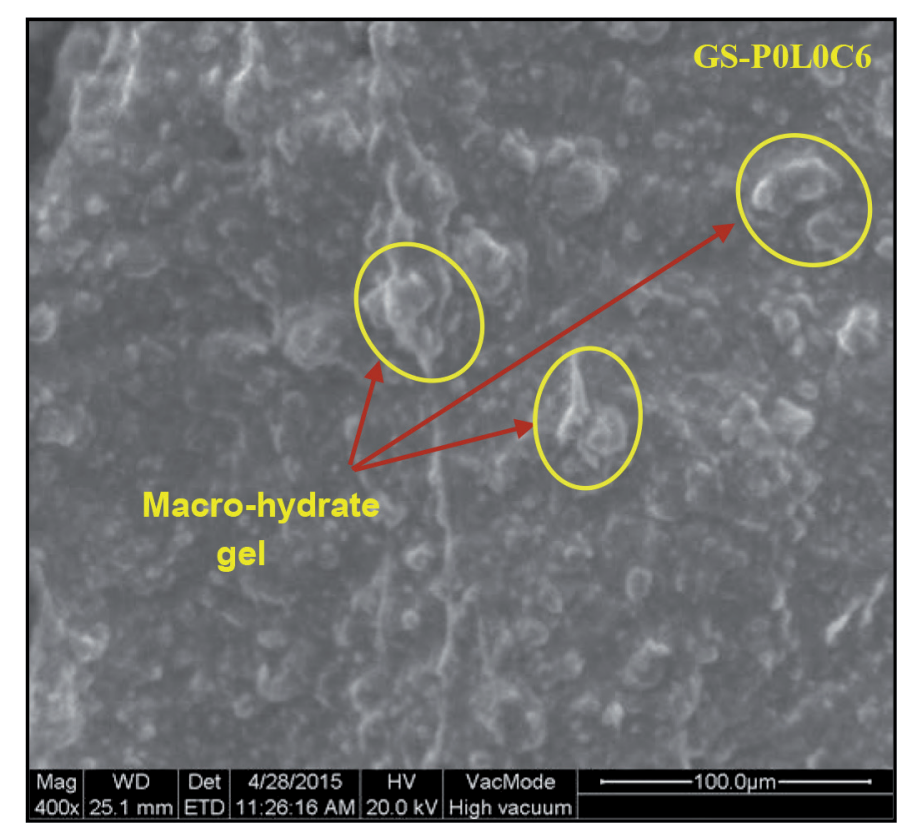

(a)

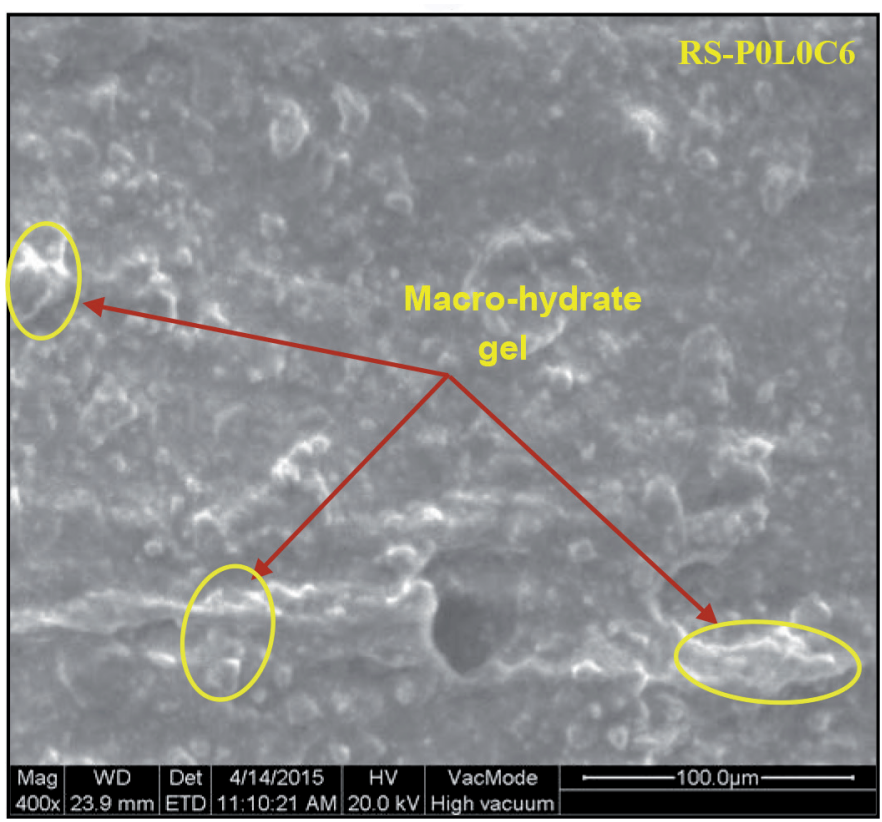

(b)

Fig. 13 SEM images show the evolution of the microstructure of both untreated GS and RS samples in the presence of $6 \% \mathrm{CaSO}_{4} \cdot 2 \mathrm{H}_{2} \mathrm{O}$ after 60 days of curing 
Whereas, for the same content of NP and curing period the UCS of the RS increases from 1.2 MPa up to 4.8 and $8.6 \mathrm{MPa}$ respectively with 2 and $6 \% \mathrm{CaSO}_{4} \cdot 2 \mathrm{H}_{2} \mathrm{O}$. However, the scanning electronic microscope (SEM) images show that the presence of $6 \%$ of $\mathrm{CaSO}_{4} \cdot 2 \mathrm{H}_{2} \mathrm{O}$ improves significantly the compactness of both untreated and NP-treated both GS and RS samples after curing for 60 days as compared with samples without $\mathrm{CaSO}_{4} \cdot 2 \mathrm{H}_{2} \mathrm{O}$ (Figs. 11-14). It is clear to see that there is a formation of macro-hydrates gel ( $\mathrm{CSH}$ and/or $\mathrm{CAH})$ in both GS and RS samples responsible on the much better change in their microstructure and the gain of strength (Figs. 13 and 14).

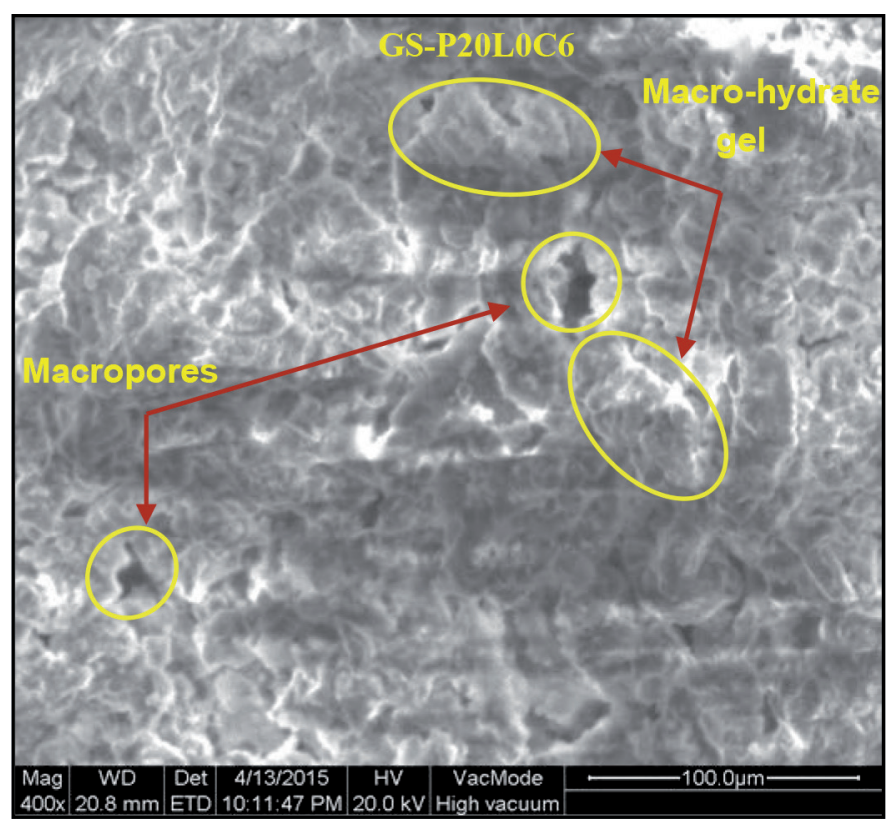

(a)

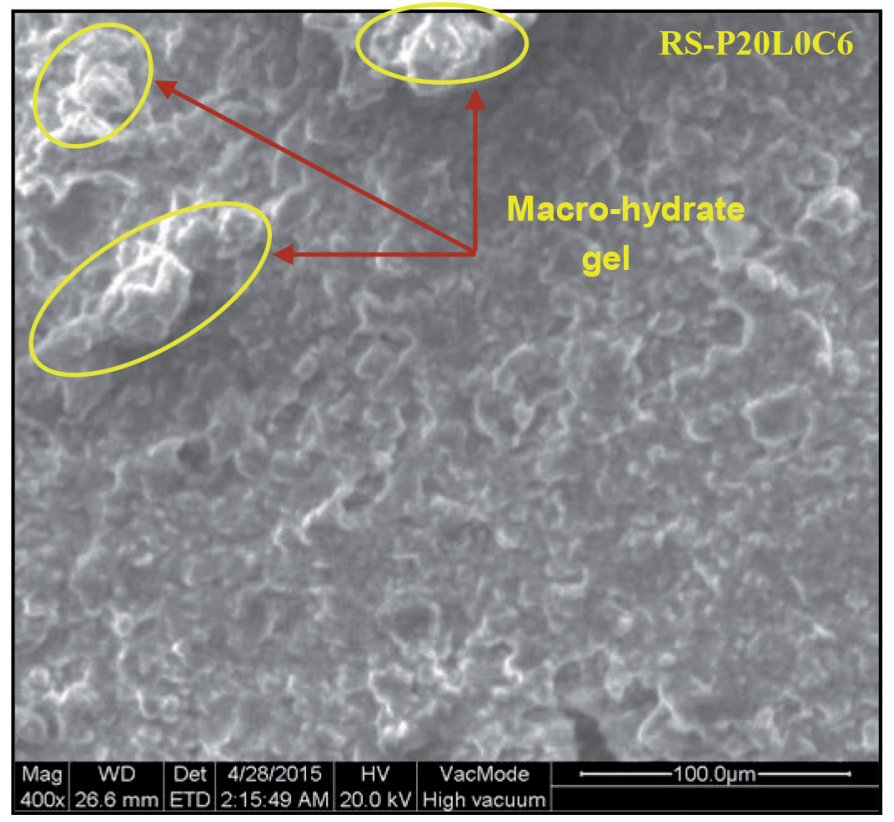

(b)

Fig. 14 SEM images show the evolution of the microstructure of NP-treated both GS and RS samples in the presence of $6 \% \mathrm{CaSO}_{4} \cdot 2 \mathrm{H}_{2} \mathrm{O}$ after 60 days of curing
Further, Aldaood et al. [18] reported that the increase in strength of L-treated gypseous soils due to the finer grained of $\mathrm{CaSO}_{4} \cdot 2 \mathrm{H}_{2} \mathrm{O}$ which increases the compactness of the matrix and consequently the UCS of soil samples. Whereas, the slight UCS values obtained for the NP-treated both GS and RS samples without $\mathrm{CaSO}_{4} \cdot 2 \mathrm{H}_{2} \mathrm{O}$ can be explained by the presence of macropores in these samples which due to the high specific surface area of NP (Fig. 12a and c).

However, the addition of $\mathrm{L}$ alone to both GS and RS samples on curing with $\mathrm{CaSO}_{4} \cdot 2 \mathrm{H}_{2} \mathrm{O}$ increases the UCS with curing period. The increase in the UCS with time can be attributed to the hydration rate due to the short time reactions between soil, $\mathrm{L}$ and gypsum to form CSH and/or CAH and ettringite [19]. In addition, Hunter [14] reported that the hydroxyl $\mathrm{OH}^{-}$retained from $\mathrm{L}$ hydration combines with montmorillonite to form aluminum compounds and then reacts with sulphates to form the ettringite mineral. However, at early stage there is a high increase in UCS of L-treated both GS and RS samples with increasing $\mathrm{CaSO}_{4} \cdot 2 \mathrm{H}_{2} \mathrm{O}$ and $\mathrm{L}$ content compared with samples cured without $\mathrm{CaSO}_{4} \cdot 2 \mathrm{H}_{2} \mathrm{O}$. In contrast, at later stage the UCS of L-treated both GS and RS samples increases slightly with increasing $\mathrm{CaSO}_{4} \cdot 2 \mathrm{H}_{2} \mathrm{O}$ and $\mathrm{L}$ content. The same behaviour was obtained by Segui et al. [16]. It is clear to see that with any content of $\mathrm{CaSO}_{4} \cdot 2 \mathrm{H}_{2} \mathrm{O}$ there is a high difference in UCS values between the NP-treated GS samples and L-treated the same soil samples. In contrast, with $2 \%$ of $\mathrm{CaSO}_{4} \cdot 2 \mathrm{H}_{2} \mathrm{O}$ and for any curing periods, both untreated and NP-treated RS samples appear to develop the same UCS values compared with the L-treated the same soil with the same content of $\mathrm{CaSO}_{4} \cdot 2 \mathrm{H}_{2} \mathrm{O}$. In addition, after 30 days of curing with 4 and $6 \%$ of $\mathrm{CaSO}_{4} \cdot 2 \mathrm{H}_{2} \mathrm{O}$ the UCS values of both untreated and NP-treated RS samples are very higher compared with those of L-treated the same soil with the same contents of $\mathrm{CaSO}_{4} \cdot 2 \mathrm{H}_{2} \mathrm{O}$. e.g., on curing with 4 and $6 \%$ of $\mathrm{CaSO}_{4} \cdot 2 \mathrm{H}_{2} \mathrm{O}$ the RS stabilized with $20 \% \mathrm{NP}$ develop respectively UCS values of 7.2 and $8.6 \mathrm{MPa}$ after curing for 120 days. Whereas, for the same contents of $\mathrm{CaSO}_{4} \cdot 2 \mathrm{H}_{2} \mathrm{O}$ the RS stabilized with $8 \% \mathrm{~L}$ develop respectively UCS values of 5.4 and $5.7 \mathrm{MPa}$ after the same curing period. The little increase in the UCS of L-treated RS as compared with the NP-treated the same soil is due to the fact that the $\mathrm{CaSO}_{4} \cdot 2 \mathrm{H}_{2} \mathrm{O}$ has the capacity to reduce the solubility of hydrated L (Shi and Day, 2000) [34]. Furthermore, in all cases the increase in UCS values with increasing $\mathrm{CaSO}_{4} \cdot 2 \mathrm{H}_{2} \mathrm{O}$ content and curing period is more pronounced in the RS than in the GS. This leading us to suggest that the increase in UCS values could be due to the behaviour of the RS with the $\mathrm{CaSO}_{4} \cdot 2 \mathrm{H}_{2} \mathrm{O}$ interaction.

However, the UCS of both GS and RS samples stabilized with a combination of L-NP increases sharply with increasing $\mathrm{CaSO}_{4} \cdot 2 \mathrm{H}_{2} \mathrm{O}$ content, L-NP content and curing period whereby RS has the best results (Fig. 10). E.g., with $2 \%$ of $\mathrm{CaSO}_{4} \cdot 2 \mathrm{H}_{2} \mathrm{O}$ both GS and RS stabilized with the combination $10 \% \mathrm{NP}+4 \% \mathrm{~L}$ develop an UCS value of 3.8 and $7.4 \mathrm{MPa}$ after curing for 120 
days, respectively. But with the same content of $\mathrm{CaSO}_{4} \cdot 2 \mathrm{H}_{2} \mathrm{O}$ and curing period the UCS of both GS and RS stabilized with $20 \% \mathrm{NP}+8 \% \mathrm{~L}$ becomes 7.1 and $8.8 \mathrm{MPa}$, respectively.

However, on curing with $6 \%$ of $\mathrm{CaSO}_{4} \cdot 2 \mathrm{H}_{2} \mathrm{O}$ both $\mathrm{GS}$ and RS stabilized with the combination $10 \% \mathrm{NP}+4 \% \mathrm{~L}$ develop an UCS of 5.8 and $8 \mathrm{MPa}$ after curing for 120 days, respectively. Whereas, for the same content of $\mathrm{CaSO}_{4} \cdot 2 \mathrm{H}_{2} \mathrm{O}$ and curing period the UCS of two GS and RS stabilized with $20 \% \mathrm{NP}+8 \% \mathrm{~L}$ becomes 8.7 and $9.9 \mathrm{MPa}$, respectively. Generally, the early increase in the UCS of both GS and RS samples can be explained by the presence of $\mathrm{CaSO}_{4} \cdot 2 \mathrm{H}_{2} \mathrm{O}$ which accelerates the chemical reaction between soil and $\mathrm{L}$ to form ettringite by the reaction of $\mathrm{SO}_{4}^{2-}$ with the $\mathrm{CSH}$ and $\mathrm{CAH}$ from pozzolanic reactions [18].

\section{Conclusions}

Soil stabilisation with $\mathrm{L}$ alone or in combination with NP in the presence of $\mathrm{CaSO}_{4} \cdot 2 \mathrm{H}_{2} \mathrm{O}$ is away to decrease the PI and increase the UCS of both clayey soils. Based on the test results, the following conclusions can be drawn:

1. The addition of $\mathrm{L}$ to both GS and RS samples produces a significant reduction in the PI which decreases with increasing L content. The use of NP without $\mathrm{CaSO}_{4} \cdot 2 \mathrm{H}_{2} \mathrm{O}$ reduces slightly the PI of both GS and RS samples. The combination of L-NP without $\mathrm{CaSO}_{4} \cdot 2 \mathrm{H}_{2} \mathrm{O}$ decreases significantly the PI of both GS and RS samples more than the use of $\mathrm{L}$ alone.

2. The use of $\mathrm{CaSO}_{4} \cdot 2 \mathrm{H}_{2} \mathrm{O}$ as an additive reduces considerably the PI of both GS and RS samples. The degree of reduction depends largely on the mineralogical composition of the soil, the type and the amount of mineral additives, the $\mathrm{CaSO}_{4} \cdot 2 \mathrm{H}_{2} \mathrm{O}$ content and the curing period.

3. The stabilization with $\mathrm{L}$ alone without $\mathrm{CaSO}_{4} \cdot 2 \mathrm{H}_{2} \mathrm{O}$ increases considerably the UCS of both GS and RS samples. This increase depends on the amount of $\mathrm{L}$ added and the curing period. However, a negligible influence on the UCS of both GS and RS samples containing $\mathrm{CaSO}_{4} \cdot 2 \mathrm{H}_{2} \mathrm{O}$ is observes when the NP is used alone.

4. The high early values of UCS developed by both GS and RS samples with curing period can be attributed to the acceleration of the pozzolanic reaction due to the $\mathrm{CaSO}_{4} \cdot 2 \mathrm{H}_{2} \mathrm{O}$ added.

5. The $\mathrm{CaSO}_{4} \cdot 2 \mathrm{H}_{2} \mathrm{O}$ has a marginal influence on the UCS of both GS and RS samples stabilized with lime alone.

6. The mineralogical composition of the clayey soil plays an important role in the chemical reaction with $\mathrm{CaSO}_{4} \cdot 2 \mathrm{H}_{2} \mathrm{O}$.

7. The progressive increase in the UCS of both GS and RS, particularly the RS, can be explained by the formation of ettringite due to the presence of $\mathrm{CaSO}_{4} \cdot 2 \mathrm{H}_{2} \mathrm{O}$ in the Soil-L-NP system. Indeed, the increase in UCS values is particularly important when the amount of $\mathrm{CaSO}_{4} \cdot 2 \mathrm{H}_{2} \mathrm{O}$ increases.
8. Economically, the $\mathrm{CaSO}_{4} \cdot 2 \mathrm{H}_{2} \mathrm{O}$ is cheaper and technically it can be used alone for clayey soil as a stabilizer and accelerator for pozzolanic reactions. Moreover, their effect becomes very high when it is mixed with NP alone.

\section{Acknowledgements}

The authors acknowledge the Pr. Said Kenai, Pr. Khaled Grine and Dr. Othmane Boukendakdji for their providing language help and for precious comments to improve the scientific quality of this paper. We thank the director of the "Laboratoire de l'Habitat et de la Construction Centre (LHCC)" (translation in English, Habitat Laboratory and Construction Center), Rouiba and Oued Smar, Algeria" for providing excellent working conditions and financial support. We also thank the technicians of the LHCC for their help during the experimental work, without them this study would not have been possible. Furthermore, our thanks are also addressed to the head of the Hydraulic Department and the technicians of the Hydraulic Laboratory of Chlef University.

\section{References}

[1] Kolias, S., Kasselouri-Rigopoulou, V., Karahalios. A. "Stabilization of clayey soils with high calcium fly ash and cement" Cement and Concrete Composites. 27, pp. 301-313. 2005. DOI: 10.1016/j.cemconcomp.2004.02.019

[2] Afès, M., Didier, G. "Stabilisation des sols gonflants: cas d'une argile en provenance de Mila (Algérie)." Bulletin of Engineering Geology and the Environment. 59(1). pp. 75-83. 2000. DOI: 10.1007/s100649900022

[3] Le Borgne, T. "Effects of potential deleterious chemical compounds on soil stabilization.” Ph.D. dissertation, Nancy-University, French, 2010. URL: http://hdl.hadle.net/10068/842439

[4] Asgari, M. R., Dezfuli, A. B., Bayat, M. "Experimental study on stabilization of a low plasticity clayey soil with cement/lime." Arabian Journal of Geosciences. 8(3), pp. 1439-1452. 2015. DOI: 10.1007/s12517-0131173-1

[5] Rahman, M. D. A. "The potentials of some stabilizers for the use of lateritic soil in construction.” Building and Environment. 21(1), pp. 57-61. 1986. DOI: 10.1016/0360-1323(86)90008-9

[6] Basha, E. A., Hashim, R., Muntohar, A. S. "Effect of the cement-rice husk ash on the plasticity and compaction of soil." Electronic Journal of Geotechnical Engineering. 8(1), pp. 1-8. 2003. URL: http:/www.ejge. com/2003/Ppr0304/Abs0304.htm

[7] Choobbasti, A. J., Ghodrat, H., Vahdatirad, M. J., Firouzian, S., Barari, A., Torabi, M., Bagherian, A. "Influence of using rice husk ash in soil stabilization method with lime." Frontiers of Earth Science. 4(4), pp. 471-480. 2010. DOI: 10.1007/s11707-010-0138-x

[8] Goswami, R. K., Singh, B. "Influence of Fly Ash and Lime on Plasticity characteristics of Residual Lateritic Soil." Proceedings of the Institution of Civil Engineers - Ground Improvement. 9(4), pp. 175-182. 2005. DOI: 10.1680 /grim.2005.9.4.175

[9] Hossain, K. M. A., Lachemi, M., Easa, S. "Stabilized soils for construction applications incorporating natural resources of Papua New Guinea." Resources, Conservation and Recycling. 51(4), pp. 711-731. 2007. DOI: 10.1016/j.resconrec.2006.12.003

[10] Harichane, K., Ghrici, M., Kenai, S., Grine, K. "Use of natural pozzolana and lime for stabilization of cohesive soil." Geotechnical and Geological Engineering, 29(5), pp. 759-769. 2011. DOI: 10.1007/s10706-011-9415-z 
[11] Harichane, K., Ghrici, M., Kenai, S. "Effect of curing period on shear strength of cohesive soils stabilized with combination of lime and natural pozzolana." International Journal of Civil Engineering, 9(2), pp. 90-96. 2011. URL: http://www.sid.ir/EN/VEWSSID/J_pdf/86220110202.pdf

[12] Yunus, N. Z. M., Wanatowski, D., Hassan, N. A., Marto, A. "Shear strength and compressibility behaviour of lime-treated organic clay." KSCE-Journal of Civil Engineering. 20(5), pp. 1721-1727. 2016. DOI: 10.1007/s12205-015-0438-5

[13] Kinuthia, J. M., Wild, S., Jones, G. I. "Effects of monovalent and divalent metal sulphates on consistency and compaction of lime-stabilized kaolinite." Applied Clay Science. 14(1), pp. 27-45. 1999.

[14] Hunter, D. "Lime-induced heave in sulphate-bearing clay soils." ASCE Journal of Geotechnical Engineering. 114(2), pp. 150-167. 1988. DOI: 10.1061/(ASCE)0733-9410(1988)114:2(150)

[15] Sivapullaiah, P. V., Sridharan, A., Ramesh, H. N. "Strength behaviour of lime-treated soils in the presence of sulphate." Canadian Geotechnical Journal. 37(6), pp. 1358-1367. 2000. DOI: 10.1139/t00-052

[16] Segui, P., Aubert, J. E., Husson, B., Measson, M. "Utilization of a natural pozzolan as the main component of hydraulic road binder." Construction and Building Materials. 40, pp. 217-223. 2013. DOI: 10.1016/j. conbuildmat.2012.09.085

[17] Puppala, A. J., Talluri, N., Chittoori, B. C. "Calcium-based stabiliser treatment of sulfate-bearing soils." Proceedings of the Institution of Civil Engineers - Ground Improvement. 167(3), pp. 162-172. 2014. DOI: 10.1680/grim.13.00008

[18] Aldaood, A., Bouasker, M., Al-Mukhtar, M. "Geotechnical properties of lime-treated gypseous soils.” Applied Clay Science. 88-89, pp. 39-48. 2014. DOI: 10.1016/j.clay.2013.12.015

[19] Aldaood, A., Bouasker, M., Al-Mukhtar, M. "Impact of wetting-drying cycles on the microstructure and mechanical properties of lime-stabilized gypseous soils." Engineering Geology. 174, pp. 11-21. 2014. DOI: 10.1016/j.enggeo.2014.03.002

[20] Ghrici, M., Kenai, S., Said Mansour, M. "Mechanical properties and durability of mortar and concrete containing natural pozzolana and limestone blended cements." Cement and Concrete Composites. 29(7), pp. 542-549. 2007. DOI: 10.1016/j.cemconcomp.2007.04.009

[21] Harichane, K., Ghrici, M., Missoum, H. "Influence of natural pozzolana and lime additives on the temporal variation of soil compaction and shear strength." Frontiers of Earth Science. 5(2), pp. 162-169. 2011. DOI: 10.1007/s11707-011-0166-1

[22] Harichane, K., Ghrici, M., Kenai, S. "Effect of the combination of lime and natural pozzolana on the compaction and strength of soft clayey soils: a preliminary study." Environmental Earth Sciences. 66(8), pp. 2197-2205. 2012. DOI: 10.1007/s12665-011-1441-x
[23] ASTM D4318 "Standard test methods for liquid limit, plastic limit and plasticity index of soils." ASTM-American Society for Testing and Materials, West Conshohocken, Pennsylvania, USA, 2000. DOI: 10.1520/D4318

[24] ASTM D2166 "Standard test method for unconfined compressive strength of cohesive soil." ASTM-American Society for Testing and Materials, West Conshohocken, Pennsylvania, USA, 2000. DOI: $10.1520 / \mathrm{D} 2166 \_$D2166M

[25] Yong, R. N., Ouhadi, V. R. "Experimental study on instability of bases on natural and lime/cement-stabilized clayey soils." Applied Clay Science. 35(3), pp. 238-249. 2007. DOI: 10.1016/j.clay.2006.08.009

[26] Attoh-Okine, N. O. "Lime treatment of laterite soils and gravels-revisited." Construction and Building Materials. 9(5), pp. 283-287. 1995. DOI: 10.1016/0950-0618(95)00030-J

[27] Sivrikaya, O., Yavascan, S., Cecen, E. "Effects of ground granulated blast furnace slag on the index and compaction parameters of clayey soils." Acta Geotechnica Slovenica. 11, pp. 19-27. 2014. URL: http:// www.fg.uni-mb.si/journal-ags/pdfs/AGS_2014-1_article_2.pdf

[28] Ansary, M. A., Noor, M. A., Islam, M. "Effect of fly ash stabilization on geotechnical properties of Chittagong coastal soil.” In: Soil stress-strain behavior: measurements, modeling and analysis. Geotechnical symposium in Roma, March 16-17, 2006, pp. 443-454. DOI: 10.1007/978-14020-6146-2_26

[29] Yilmaz, I., Civelekoglu, B. "Gypsum: an additive for stabilization of swelling clay soils.” Applied Clay Science. 44, pp. 166-172. 2009. DOI: 10.1016/j.clay.2009.01.020

[30] Yadu, L., Tripathi, R. K. "Effect of granulated blast furnace slag in the engineering behaviour of stabilized soft soil." Procedia Engineering. 51, pp. 125-131. 2013. DOI: 10.1016/j.proeng.2013.01.019

[31] Eberemu, A. O. "Evaluation of bagasse ash treated lateritic soil as a potential barrier material in waste containment application." Acta Geotechnica. 8(4), pp. 407-421. 2013. DOI: 10.1007/s11440-012-0204-5

[32] Degirmenci, N., Okucu, A., Turabi, A. “Application of Phosphogypsum in Soil Stabilization.” Building and Environment. 42(9), pp. 3393-3398. 2007. DOI: 10.1016/j.buildenv.2006.08.010

[33] McCarthy, M. J., Csetenyi, L. J., Sachdeva, A., Dhir, R. K. "Engineering and durability properties of fly ash treated lime-stabilised sulphatebearing soils." Engineering Geology. 174, pp. 139-148. 2014. DOI: 10.1016/j.enggeo.2014.03.001

[34] Shi, C., Day, R. L. "Pozzolanic reaction in the presence of chemical activators Part I. Reaction kinetics." Cement and Concrete Research. 30(1), pp. 51-58. 2000. 